\title{
Laboratory Melting of Late-Winter Urban Snow Samples: The Magnitude and Dynamics of Releases of Heavy Metals and PAHs
}

\author{
Arya Vijayan (D) Heléne Österlund • Jiri Marsalek • \\ Maria Viklander
}

Received: 19 December 2018 / Accepted: 5 June 2019 / Published online: 26 July 2019

(C) The Author(s) 2019

\begin{abstract}
Laboratory snow melting experiments were conducted with actual late-winter snow samples, collected just before the final snowmelt, in two similar northern Swedish cities, Luleå and Umeå, to investigate releases of the selected heavy metals $(\mathrm{HM})(\mathrm{Cu}, \mathrm{Pb}, \mathrm{Zn}$, and $\mathrm{Cd}$ ) and 16 USEPA PAHs from melting snow. Metal concentrations were determined in three fractions: total, dissolved, and truly dissolved (defined as the fraction passing through a 3-kMWCO ultrafilter). Total HM concentrations in snowmelt were rather high at both sites and reflected the accumulation of pollutants in the roadside snowbanks over a period of about 5 months: $\mathrm{Cd}=0.43, \mathrm{Cu}=303, \mathrm{~Pb}=41.9, \mathrm{Zn}=817(\mu \mathrm{g} / \mathrm{l})$, and $\mathrm{TSS}=2000(\mathrm{mg} / \mathrm{l})$ in Luleå samples and $\mathrm{Cd}=1.87$, $\mathrm{Cu}=905, \mathrm{~Pb}=165, \mathrm{Zn}=3150(\mu \mathrm{g} / \mathrm{l})$, and $\mathrm{TSS}=4800$ (mg/l) in Umeå samples. The difference between metal and TSS concentrations at the two sites of similar characteristics was attributed to a smaller volume snowbank in Umeå. The dissolved HM concentrations represented relatively small fractions of the total concentrations (0.3-6.9\% in Luleå and $0.01-3.1 \%$ in Umeå). The truly dissolved fraction represented $71-90 \%$ of the dissolved fraction in Luleå and 74-98\% in Umeå. At both sites, the dissolved fractions exhibited preferential elution from the laboratory snow piles. The PAHs studied (16 US EPA PAHs) were mostly particulate bound, with
\end{abstract}

\footnotetext{
A. Vijayan $(\varangle) \cdot$ H. Österlund $\cdot$ J. Marsalek $\cdot$ M. Viklander Department of Civil, Environmental and Natural Resources Engineering, Luleå University of Technology, 97187 Luleå, Sweden

e-mail: arya.vijayan@ltu.se
}

only $5-12 \%$ of the total burden contributed by the meltwater, and most dissolved concentrations below the reporting limits. PAH concentrations in the Luleå samples were about one-third to one-fourth of those in Umeå. In general, the releases of PAHs from the snowbank were delayed, compared with releases of meltwater, and showed similar release patterns as TSS.

Keywords PAHs $\cdot$ Road salt $\cdot$ Sediment $\cdot$ Snowmelt . Truly dissolved metals · Urban late-winter snow

\section{Introduction}

Seasonal snowpacks in urban areas are exposed to, and accumulate, pollutants from such sources as atmospheric deposition, operation of motor vehicles and winter road maintenance including applications of de-icing chemicals and anti-skid materials, debris from road surfaces, animal excrement, and litter (Marsalek et al. 2003). Compared with other seasons, the releases of urban pollutants are higher in cold weather, because of heating, less efficient operation of vehicles and special requirements of road maintenance (Malmquist 1978). Storage of pollutants in snowpacks is a dynamic process comprising pollutant influx, releases during intermittent snowmelts, and removal with used snow in snow clearing operations (Viklander 1997; Meyer et al. 2006). Pollutant releases include elution from snowpacks in above freezing weather, with soluble pollutants eluted early during the melting process (Colbeck 1981). 
Pollutants associated with particulate matter may be released with high rates of snowmelt (Meyer et al. 2009a), but generally remain on the ground in the solid residue at the end of the final snowmelt (Schöndorf and Herrmann 1987; Viklander 1997). Sudden releases of contaminated snowmelt during warm spells and rain-on-snow events, or direct disposal of used snow into open waters, may cause harmful impacts on the quality of the receiving water bodies (Novotny et al. 1998; Ruth 2003; Engelhard et al. 2007), including toxicity (Couillard 1982).

The reported pollutants of concern in urban snow are typically those associated with traffic: heavy metals (HMs) (Sakai et al. 1988), polycyclic aromatic hydrocarbons (PAHs) (Schrimpff et al. 1979), and road salts (Field et al. 1974; Marsalek et al. 2003). The occurrence of HMs in urban snow and snowmelt impacted by traffic is well documented with respect to: (i) sources (Sakai et al. 1988; Viklander 1998; Elik 2001; Glenn and Sansalone 2002; Sansalone and Glenn 2002; Reinosdotter and Viklander 2005; Valtanen et al. 2014; Li et al. 2015), (ii) linkage to traffic (Westerlund and Viklander 2005; Kuoppamäki et al. 2014; Moghadas et al. 2015; Markiewicz et al. 2017), (iii) transport with meltwater (Viklander 1996; Westerlund et al. 2011; Westerlund and Viklander 2011), and, to a lesser degree, (iv) impacts on the receiving environments (Malmquist 1984; Engelhard et al. 2007; Bartlett et al. 2012a, b). However, for full understanding of HM impacts and their mitigation, the knowledge of HM partitioning between the dissolved and particulate fractions, and the truly dissolved fraction, is needed (Luan and Vadas 2015).

The particulate and dissolved fractions of metals are distinguished by filtration through a $0.45-\mu \mathrm{m}$ filter: metals in the filtrate are considered the dissolved fraction, which contains free metals, complex ions, and organic and inorganic colloids (Guéguen and Dominik 2003). The truly dissolved fraction is considered to be the most toxic and bioavailable fraction (Luan and Vadas 2015) and was defined in the literature in several different ways. Buffle and Leeuwen (1992) described the truly dissolved fraction as the 'solute' and defined it somewhat generally as 'ions and molecules in the size range of a few angstroms to a few nanometers'. More recently, the truly dissolved fraction was defined as the fraction passing through a $1-\mathrm{kDa}$ ultrafilter (Wang et al. 2003), or a 3$\mathrm{kDa}$ ultrafilter (Morrison and Benoit 2005; Huerta-Diaz et al. 2007), or a $10-\mathrm{kDa}$ ultrafilter (approximately $0.003 \mu \mathrm{m}$ ) (Tuccillo 2006; Leermakers et al. 2016). In our study, we have adopted the definition by Morrison and Benoit (2005) and Huerta-Diaz et al. (2007), i.e. the fraction passing through a $3-\mathrm{kDa}$ ultrafilter.

Concerning the truly dissolved HM fractionation in urban storm runoff, only two references were found in the literature: Tuccillo (2006) noted that $\mathrm{Pb}$ and $\mathrm{Cr}$ were completely in the particulate fraction, but significant fractions of $\mathrm{Cu}$ and $\mathrm{Zn}$ were present in the truly dissolved fraction, as also confirmed by McKenzie and Young (2013) for $\mathrm{Cu}$; no references were found on truly dissolved metals in urban snowmelt.

A number of authors studied PAHs in urban snow, their release from snowpacks, and transport with snowmelt in urban catchments. In studies of urban PAH sources, the spatial sampling of an urban snowpack was used to characterize industrial (Boom and Marsalek 1988) and traffic sources (Hautala et al. 1995; Kuoppamäki et al. 2014; Wei et al. 2017), demonstrating the dependence of areal deposition on the height of release above the ground and wind transport. Releases of PAHs from snow were studied under controlled laboratory conditions by Schöndorf and Herrmann (1987), who reported that while the dissolved constituents left the snowpack early during thermal melting, as explained by Colbeck (1981), the hydrophobic substances like PAHs were released towards the end of snowmelt. Similar findings were reported by Meyer et al. (2006) and Meyer et al. (2009a,b) for melting artificial snow spiked with trace organic pollutants. At the urban watershed scale, Meyer et al. (2011) sampled an urban stream during snowmelt events and reported high mobilization of PAHs (and two pesticides) within the catchment, with the PAH flux rising at the onset of melting by three orders of magnitude.

Environmental effects of road salts were identified almost 50 years ago (Judd 1970; Field et al. 1974) and reviewed in the context of urban stormwater management in the cool temperate climate by Marsalek (2003), with respect to physical impacts (e.g. densimetric stratification impeding vertical mixing in lakes or ponds), and direct and indirect toxic effects contributing to benthic drift and reduced biodiversity. While the direct toxic effects were addressed elsewhere (e.g. Bartlett et al. (2012a, b), the indirect effects attributed to chloride presence and contribution to pollutant leaching or increased bioavailability (e.g. HM) are not well understood. Finally, the effects of urban snowmelt on water quality depend on the level of pollution of the snow, which increases with snow age (i.e. the period of pollution accumulation), but this period is rarely reported. 
To address the knowledge gaps concerning HM and PAHs occurrence in, and release from, late-winter urban roadside snow banks, with or without the presence of chloride from road salting, a study of controlled laboratory melting of actual snow samples, collected just before the final melt, was undertaken with the objectives of examining: (i) the occurrence of particulate, dissolved and truly dissolved fractions of $\mathrm{Cu}, \mathrm{Zn}$, and $\mathrm{Cd}$ in urban snow samples, (ii) the release patterns and temporal variation in metal concentrations during controlled laboratory snowmelt, with or without chemical enhancement of melting, and (iii) the occurrence of PAHs in urban snow samples, and the release patterns and temporal variation of PAH concentrations during snowmelt, with or without the chemical enhancement of melting.

\section{Materials and Methods}

This section includes descriptions of snow sampling in the field, experimental setup for controlled melting of snow samples in the laboratory, and details of sample analyses.

\subsection{Study Area and Snow Sampling}

Snow samples were collected during the winter of 2016/ 2017 in two municipalities in northern Sweden, Luleå and Umeå, with populations of 75,000 and 85,000, respectively (Fig. 1), and coordinates of $65^{\circ} 35^{\prime} 5.35^{\prime \prime}$ $\mathrm{N}$ and $22^{\circ} 9^{\prime} 24.13^{\prime \prime} \mathrm{E}$, and $63^{\circ} 49^{\prime} 33.05^{\prime \prime} \mathrm{N}$ and $20^{\circ} 15^{\prime}$ $46.93^{\prime \prime} \mathrm{E}$, respectively. These municipalities were selected for study because of their differences in road salt use policies. While in Luleå, the road salt is used sparingly at bus stops and road roundabouts, and may spread in trace amounts by cars to other locations; the city of Umeå regularly applies the road salt onto streets and roads. Otherwise, both cities are similar with respect to the size, urban development, and climate. Characteristics of the sampling sites are summarized in Table 1 and further comments follow.

Late-winter snow samples were collected from highway snowbanks at fairly open single sites in Luleå and Umeå in mid-March 2017, just before the final snowmelt. Such snow would have been subject to some minor intermittent melting, with some elution of dissolved chemicals, but the resulting meltwater would not reach the receiving waters, as opposed to the final snowmelt, which may even contribute to stream flooding.

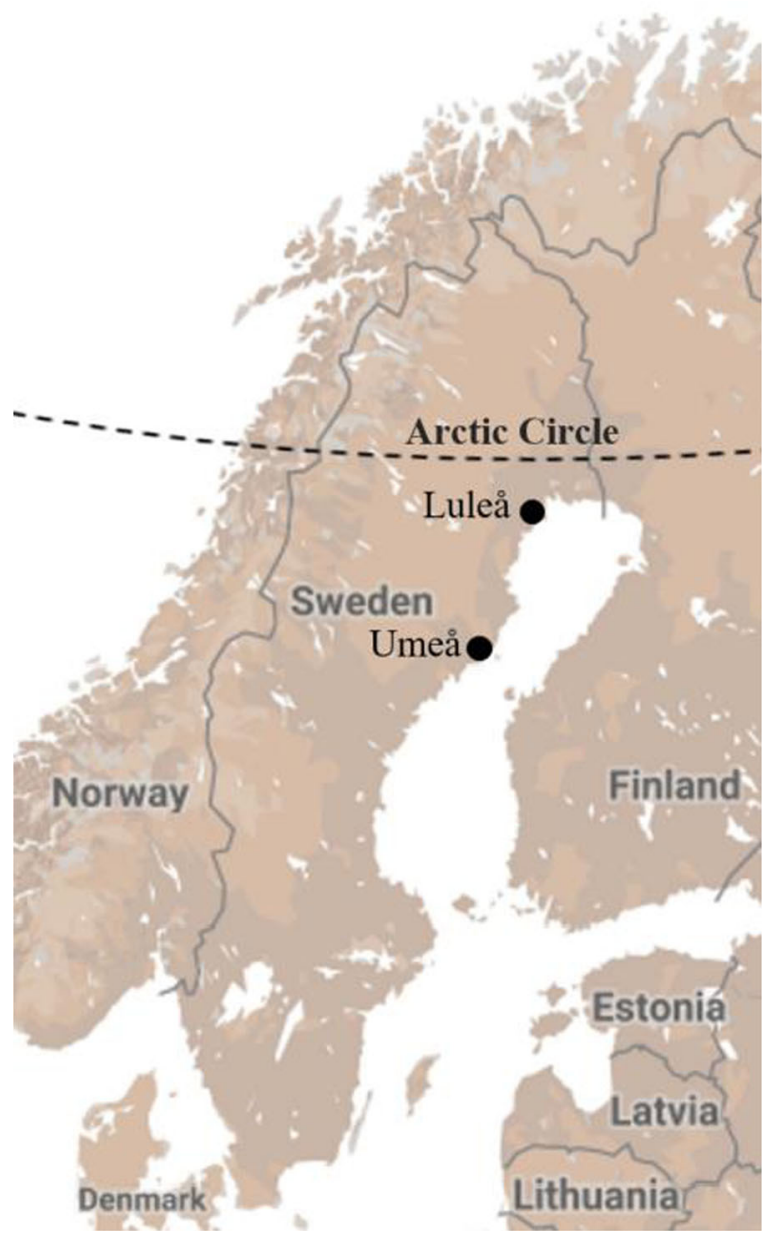

Fig. 1 Study locations, Luleå and Umeå cities, in Northern Sweden

Hence, it is the final snowmelt causing environmental concerns addressed in our study. The snowbanks were formed by snow fallen on the roadside and snow ploughed from the adjacent road pavement. Their appearance is documented in Fig. 2 and is typical for latewinter snow exposed to repeated applications of grit material. The sampled snowbank in Luleå was higher $(62 \mathrm{~cm})$ than that in Umeå $(31 \mathrm{~cm})$; this difference may be attributed to the higher snowfall at the former location during the period studied, and a higher frequency of intermittent minor snowmelts at the latter location, caused by road salt applications, more rain-on-snow events, and slightly higher temperatures. The sites differed in traffic intensity, with the Luleå site experiencing 23,900 vehicles/day compared with 17,800 vehicles/day in Umeå. The site in Luleå was located in a stretch of the road between a bus stop and a roundabout, the only 
Table 1 Basic characteristics of the sampling sites

\begin{tabular}{|c|c|c|}
\hline Characteristics & Sampling sites & \\
\hline City & Luleå & Umeå \\
\hline Snow deposit sampled & Snowbank along a highway & Snowbank along a highway \\
\hline Snowbank height (cm) & 62 & 31 \\
\hline Traffic intensity (vehicles/day) & 23,900 & 17,800 \\
\hline \multicolumn{3}{|l|}{ Antecedent weather preceding the sampling date } \\
\hline First seasonal frost date & Nov. 10, 2016 & Nov. 10, 2016 \\
\hline Sampling date & Mar. 23, 2017 & Mar. 16, 2017 \\
\hline $\begin{array}{l}\text { Precipitation (mm) after the first frost until the } \\
\text { sampling date (snow portion in brackets }[\mathrm{mm}] \text { ) }\end{array}$ & $235(155)$ & $216(108)$ \\
\hline Use of salt & Only at bus stops and roundabouts & On urban streets and roads \\
\hline
\end{tabular}

places where road salt was applied, and was exposed to minimal salt quantities carried on car underbodies and tires. On the other hand, the Umeå site was exposed to regular salt applications throughout the winter period.

Snow samples were collected by drilling vertical holes through the snow banks, using a titanium ice drill $1 \mathrm{~m}$ long and $12 \mathrm{~cm}$ in diameter. The depth and diameter of the sampling holes were measured and recorded. It was noted that a layer of ice was present at the bottom of the Umeå snowbank, as a result of freezing of a layer of wet snow. The presence of wet snow at this location may be attributed to salt applications and rain-on-snow events. Wet snow combined with reduced insulation underneath a small snowbank (height $=31 \mathrm{~cm}$ ) then contributed to ice formation. After drilling each hole, the drill was removed, wiped clean to prevent contamination, and snow was removed manually from the hole, using gloves, and placed in individual plastic bags. The bags with snow samples were labelled, placed in insulated coolers with freezer blocks to prevent sample

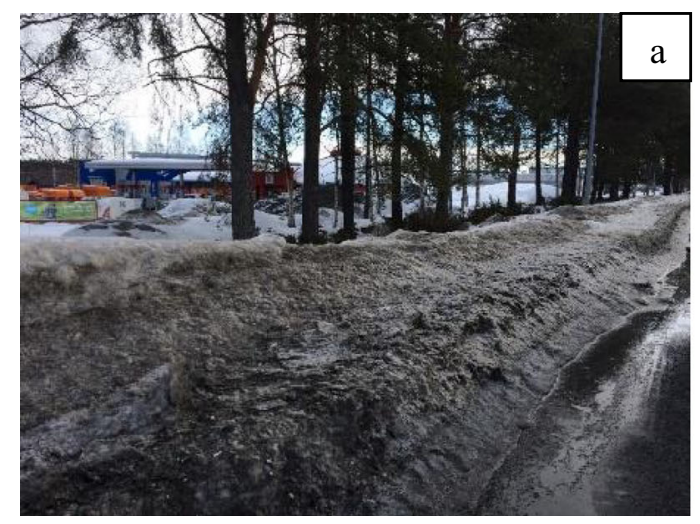

Fig. 2 Snowbanks on the sampling day: a Luleå, b Umeå melting during transport, transported in the frozen state to the laboratory, and stored in climate rooms at $-10{ }^{\circ} \mathrm{C}$.

Finally, the period of snow accumulation at both sampling sites was documented by weather records of daily precipitation and maximum temperatures, downloaded from the Swedish Meteorological and Hydrological Institute (SMHI) website, for a period of about 5 months (mid-October 2016 to mid-March 2017)(Fig. 3). Comparison of records at both sites indicates somewhat higher precipitation in Luleå, particularly in the form of snow, but close similarity of daily maximum temperature records, with frequent excursions of temperatures above $0{ }^{\circ} \mathrm{C}$, leading to intermittent snowmelts and snow bank consolidation.

\subsection{Laboratory Setup for Controlled Melting of Snow Samples}

Snow samples from the two sampling sites were separately processed in the laboratory in a similar way by

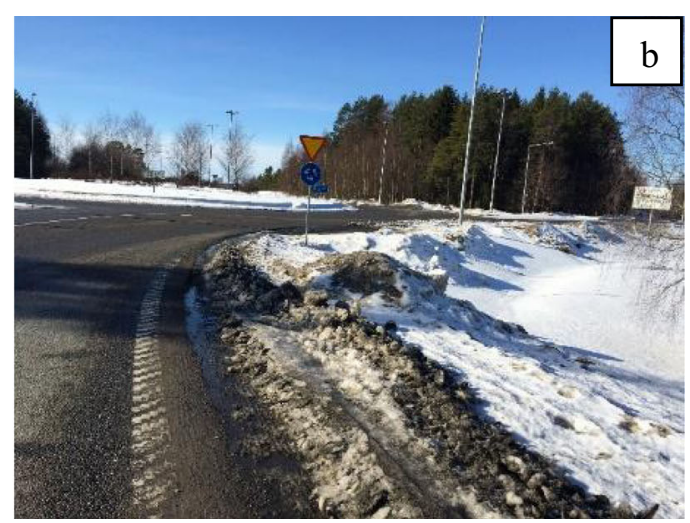



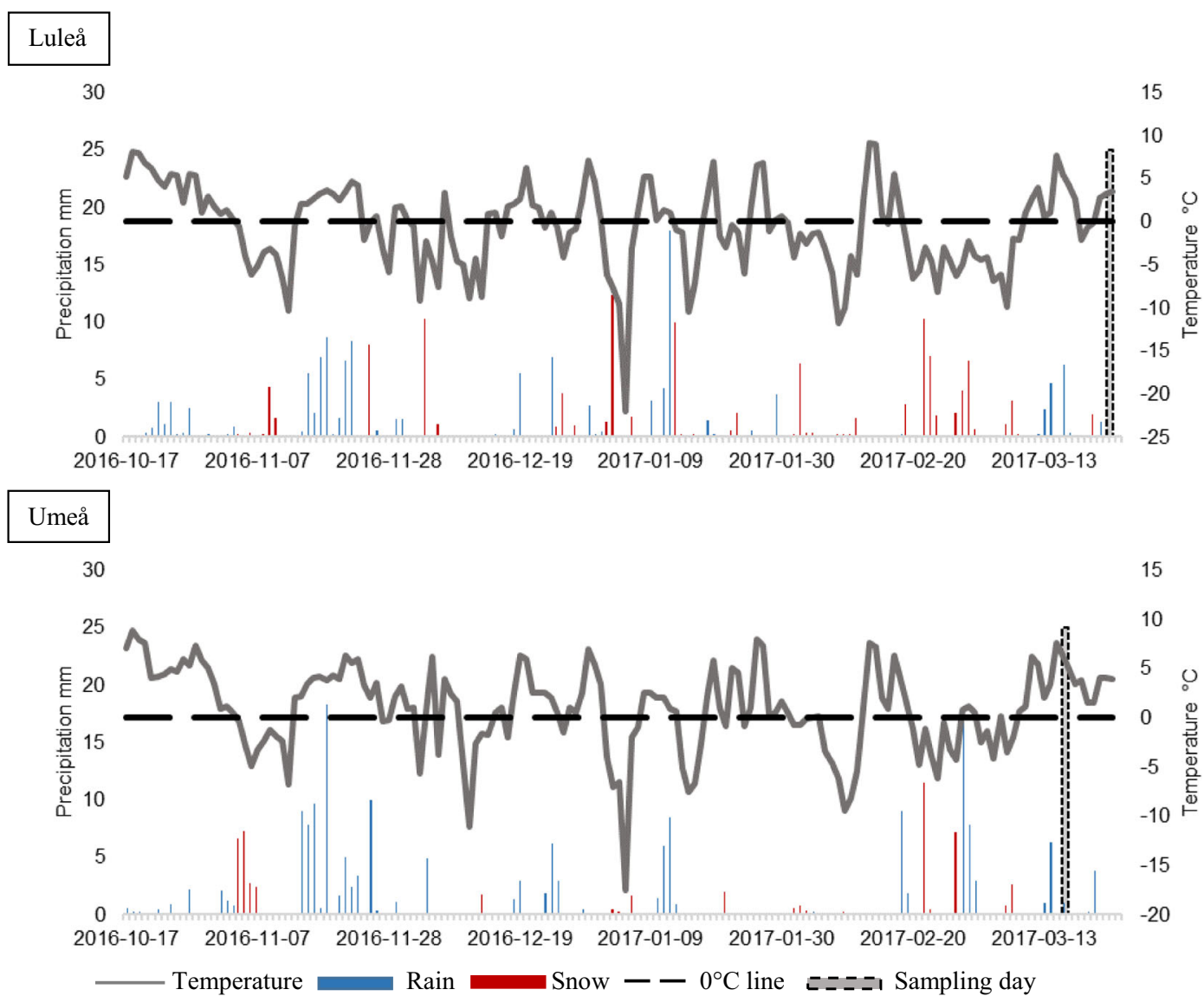

Fig. 3 Daily maximum temperature and precipitation data for Luleå (top panel) and Umeå (bottom panel) cities from October 2016 to March 2017 (source: Swedish Meteorological and Hydrological Institute)

homogenizing the snow, extracting a 5-1 snow sample for characterizing the initial quality of the homogenized snow, and forming laboratory snow piles in the shape of truncated cones to be used in melting experiments. Working in a room with controlled temperature of $-10{ }^{\circ} \mathrm{C}$, snow samples from individual sites were placed in a stainless steel box $80 \times 60 \times 22 \mathrm{~cm}$ (width $\times$ length $\times$ height) and mixed thoroughly with stainless steel axe and shovel to make a homogenous mixture. Volumetric snow samples (51) were extracted from the homogenous mixture, labelled 'initial snow-Luleå' or 'initial snow-Umeå', melted in Teflon-lined glass beakers at room temperatures, and analysed for $\mathrm{pH}$, conductivity, total suspended solids (TSS), loss on ignition (LOI), PAHs, and selected heavy metals. The remaining snow was used to make three snow piles of approximate volumes of 151 each, for each study site. For making the piles, a stainless steel mould, with a Teflon liner, was placed on a Teflon-lined stainless steel base plate, and the whole setup was weighed. The mould was then filled with the homogenized snow, working in layers and compacting snow with a stainless steel rod to achieve a snow pile density of about $0.6 \mathrm{~kg} / \mathrm{l}$ of snow. Then the cone mould was carefully removed to retain the preformed pile shape. The initial volume and weight of this pile were measured and the density was calculated. This procedure was repeated to make three replica piles for each site, for assessing the variability associated with snow samples. All the equipment was thoroughly cleaned before making the next pile. To reflect the snow quality in Umeå, where roads are salted in winter, but much of salt from road maintenance applications left the snowpack during intermittent minor melts, $60 \mathrm{~g}$ of commercial road salt were added to the homogenized snow to replenish the salt content and achieve a conductivity of snowmelt around $200 \mathrm{mS} / \mathrm{cm}$. Such a value was measured in the melted snow samples collected at the same location in a different study. 
All the six piles were placed on Teflon-lined melting trays, with a bottom slope of 5\%, and allowed to melt in a controlled temperature room at $6 \pm 0.8^{\circ} \mathrm{C}$. Snowmelt from the laboratory piles was collected in glass beakers with Teflon bags placed below the tray spouts. The weight of snowmelt was measured at regular intervals by a weighing balance with precision of $0.01 \mathrm{~g}$, and the bags were replaced when the snowmelt weight was about $1.5 \mathrm{~kg}$. This procedure was continued until four consecutive samples were collected from each pile. The rest of the snowmelt was collected as the fifth sample of a somewhat varying volume. It took up to 6 days to warm up the snow piles and melt them completely. The homogeneous mixture of snow and one of the snow piles at the beginning and end of the melt experiment are shown in Fig. 4.

\subsection{Laboratory Analyses}

Analyses of $\mathrm{pH}$, conductivity, total suspended solids (TSS), loss on ignition (LOI), and chloride $\left(\mathrm{Cl}^{-}\right)$of all study samples were done in the laboratory of Luleå University of Technology (Luleå). $\mathrm{pH}$ was measured at room temperature by the $\mathrm{pH} 330$ WTW Sigma-Aldrich instrument with an accuracy of $0.01 \mathrm{pH}$ unit and conductivity by the Radiometer analytical CDM210 conductivity meter with an accuracy of $\pm 0.2 \%$ of the reading. For TSS, the melted snow samples were vacuum filtered through a pre-dried and pre-weighed glass microfiber filter with an average pore size of $1.6 \mu \mathrm{m}$ (Whatman GF/A glass microfiber filter) as specified in the Water Investigations Method SS-EN 872:2005 (Swedish Standards Institute 2005). The filter with residue was dried in the oven at $105 \pm 2{ }^{\circ} \mathrm{C}$ for about $3 \mathrm{~h}$ and the dry residue on the filter was weighed by a weighing balance with a precision of $0.00001 \mathrm{~g}$. The filter was then placed in a furnace at $550{ }^{\circ} \mathrm{C}$ for $1 \mathrm{~h}$ and weighed, and LOI was calculated by the SS 028112 method. For the analysis of chlorides, QuAAtro method No. Q-006-04 Rev. 0 (multitest MT9/MT10) was used. In this method, thiocyanate ions are liberated from mercuric thiocyanate by chloride ions, with the formation of non-ionised, but soluble, mercuric chloride. In the presence of ferric ion, the liberated thiocyanate forms highly coloured ferric thiocyanate, measured at $480 \mathrm{~nm}$. The accuracy of the method is $10 \%$ of the measured value.

Analyses of HMs and PAHs were done by an accredited commercial laboratory, ALS Scandinavia $\mathrm{AB}$, Luleå. Among $\mathrm{HMs}, \mathrm{Pb}, \mathrm{Cu}, \mathrm{Zn}$, and $\mathrm{Cd}$ were selected for our study, because they are relatively ubiquitous in urban runoff and snowmelt, may occur at toxic levels, and were extensively reported on in previous
Fig. 4 Laboratory melting of snow samples: a Homogenized snow mixture, b Snow pile at the start of melting, $\mathbf{c}$ Sediment residue after melting
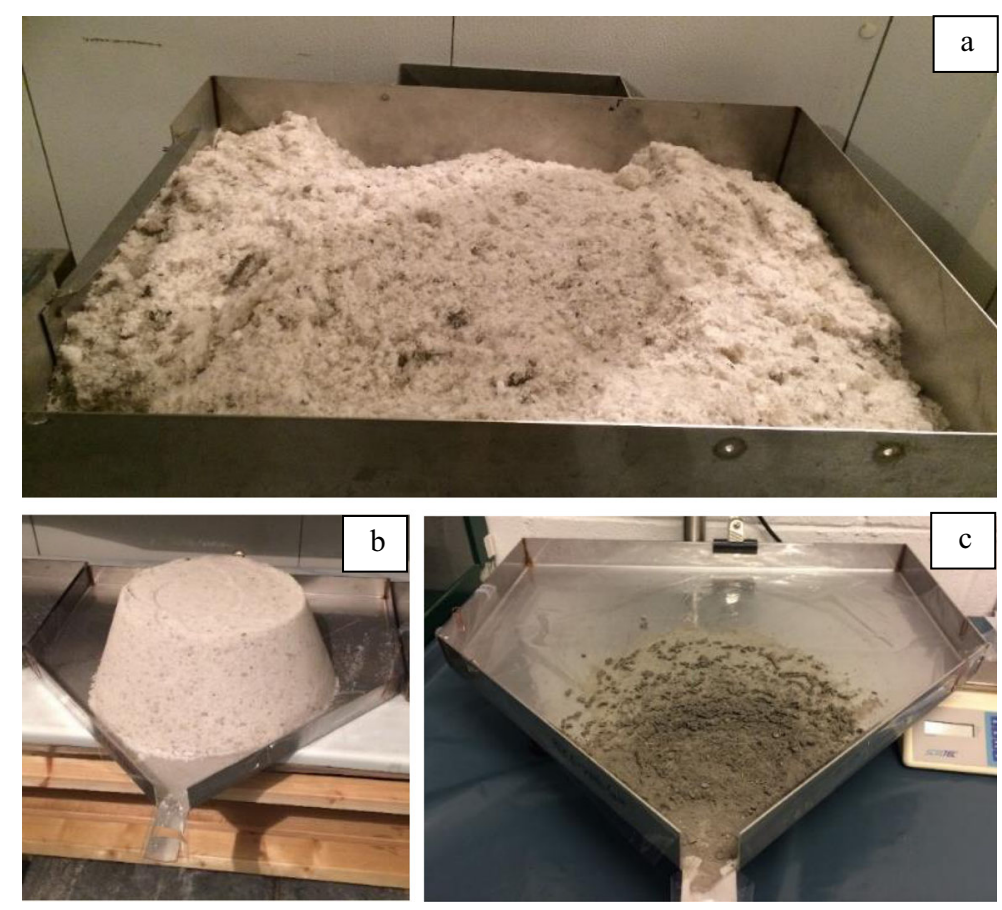
studies. $\mathrm{Na}$ and $\mathrm{Cl}$ were included in our study as tracers of the road salt. Total concentrations of $\mathrm{Pb}, \mathrm{Cu}$, and $\mathrm{Cd}$ were analysed using the inductively coupled plasma sector field mass spectrometry (ICP SFMS; SS-EN ISO 17294-1, 2 and US EPA method 200.8). Total Zn and $\mathrm{Na}$ were analysed using the inductively coupled plasma optical emission spectroscopy (ICP OES; SSEN ISO 11885 and US EPA method 200.7). The reporting limits for total metals were $\mathrm{Pb} 0.5 \mu \mathrm{g} / \mathrm{l}, \mathrm{Cu}$ $1 \mu \mathrm{g} / \mathrm{l}, \mathrm{Cd} 0.05 \mu \mathrm{g} / \mathrm{l}, \mathrm{Zn} 4 \mu \mathrm{g} / \mathrm{l}$, and $\mathrm{Na} 500 \mu \mathrm{g} / \mathrm{l}$. Dissolved metal concentrations were measured with the same techniques but after filtering the snowmelt through a $0.45 \mu \mathrm{m}$ polyether sulfone (PES) membrane filter. The reporting limits for dissolved metals were $\mathrm{Pb}$ $0.01 \mu \mathrm{g} / \mathrm{l}, \mathrm{Cu} 0.1 \mu \mathrm{g} / \mathrm{l}, \mathrm{Cd} 0.002 \mu \mathrm{g} / \mathrm{l}$, and Zn $0.2 \mu \mathrm{g} / \mathrm{l}$.

In order to determine the truly dissolved metals, the snowmelt was first filtered through the $0.45 \mu \mathrm{m}$ PES membrane filter, and $20 \mathrm{ml}$ of the filtrate was poured into a Sartorius Vivaspin 20 ultrafilter device with a molecular weight cut-off (MWCO) of 3000. The ultrafilter device was then placed in a centrifuge and spun at $4000 \mathrm{rpm}$ for 60 to $90 \mathrm{~min}$. For analysing truly dissolved Zn, the ICP OES method (EE EN ISO 11885 and US EPA 200.7) and for $\mathrm{Cd}$ and $\mathrm{Cu}$, ICP SFMS (SS-EN ISO 17294-1, 2 and US EPA method 200.8) were used.

The snowmelt samples were analysed for the following 16 PAHs: Naphthalene (Nap), Acenaphthene (Ace) Acenaphthylene (Acy), Fluorene (Flu), Phenanthrene (Phe), Anthracene (Ant), Fluoranthene (Flt), Pyrene (Pyr), Benzo[a]anthracene (BaA), Chrysene (Chr), Benzo[b]fluoranthene $(\mathrm{BbF})$, Benzo[k]fluoranthene $(\mathrm{BkF})$, Benzo[a]pyrene (BaP), Indeno[1,2,3]pyrene (IndP), Dibenzo[a,h]anthracene (DahA), and Benzo[ghi]perylene (BghiP). PAHs were measured using the US EPA 8270 and CSN EN ISO 6468 methods. To analyse dissolved PAHs, the snowmelt samples were first filtered through $0.45 \mu \mathrm{m}$ PTFE (polytetrafluoroethylene) membrane filters and the same analytical method as for total PAHs was applied. The reporting limits for total and dissolved PAHs were as follows: Nap-0.03 $\mu \mathrm{g} / 1$; Phe $-0.02 \mu \mathrm{g} / 1$; Ace, Acy, Flu, Ant, Flt, Pyr, BaA, Chr, BbF, BkF, BaP, IndP, DahA, and BghiP $-0.01 \mu \mathrm{g} / \mathrm{l}$. Some of the measured data fell below the reporting limit and represented censored data. Several methods of various complexity are used when dealing with environmental datasets containing censored data: setting the values below the reporting limit equal to zero or the reporting limit divided by the square root of two (Croghan and Egeghy 2003), or by two, or using the maximum likelihood estimation. For practical reasons, the widely used and cited simple method of substitution of one-half of the reporting limit (Helsel 1990) was adopted in this study.

The sediment residues left on the Teflon liner at the end of melting were collected separately, weighed, sieved through a 2-mm stainless steel sieve, and submitted to an accredited laboratory for PAHs analyses. The PAHs in the sediment residue were measured by GCMS/HPLC. The reporting limit for all 16 PAHs was $0.01 \mathrm{mg} / \mathrm{kg}$ of dry weight.

\section{Results}

\subsection{Initial Homogenized Snow Quality}

The initial snow quality was defined here as a chemical characterization of snowmelt from the initial 51 snow samples extracted from the homogenized snow mixture before making the lab snow piles. The results of chemical characterization of the initial snow samples from Luleå and Umeå, obtained by analysis of their snowmelt, are presented in Tables 2, 3, and 4 for physicochemical parameters, HMs, and PAHs. Concerning the physicochemical parameters (Table 2), three differences between the two sampling sites stand out: TSS concentrations in Umeå snow $(4800 \pm 470 \mathrm{mg} / \mathrm{l})$ were about 2.5 times greater than in Luleå $(2000 \pm 170 \mathrm{mg} / \mathrm{l})$, conductivity was about an order of magnitude higher in the Umeå snow $(180 \mathrm{mS} / \mathrm{cm})$ compared with Luleå $(21 \mathrm{mS} / \mathrm{cm})$, and chlorides were also an order of magnitude higher in the Umeå snow $(725 \pm 5 \mathrm{mg} / \mathrm{l})$ compared with Luleå (66 $\pm 0 \mathrm{mg} / \mathrm{l})$. Higher TSS concentrations in Umeå snow likely resulted from the smaller height (volume) of snowbank at this site (Table 1) and, therefore, a greater concentration of comparable quantities of grit material applied at both sites, and the high conductivity and chlorides resulting from road salting in Umea and the salt addition to the homogenized snow sample.

The HMs selected for study $(\mathrm{Pb}, \mathrm{Cu}, \mathrm{Zn}$, and $\mathrm{Cd}$ ) were also analysed in the melted homogenized (initial) snow samples, and the results are shown in Table 3 for the total, dissolved, and truly dissolved fraction concentrations of the metals studied.

Total HMs in the initial snow samples were found in appreciable concentrations, reflecting the total snow accumulation at both sites of the duration of about 134 days (i.e. from Nov. 7, 2016, to March 16-23, 
Table 2 Physicochemical parameters of homogenized snow samples from Luleå and Umeå

\begin{tabular}{|c|c|c|c|c|c|}
\hline Sample & $\begin{array}{l}\mathrm{TSS}(\mathrm{mg} / \mathrm{l}) \\
\text { mean } \pm \mathrm{SD}^{*}\end{array}$ & $\begin{array}{l}\mathrm{LOI}(\mathrm{mg} / \mathrm{l}) \\
\text { mean } \pm \mathrm{SD}^{*}\end{array}$ & $\mathrm{pH}$ & $\begin{array}{l}\text { Conductivity } \\
(\mathrm{mS} / \mathrm{cm})\end{array}$ & $\begin{array}{l}\text { Chloride } \\
(\mathrm{mg} / \mathrm{l}) \\
\text { mean } \pm \mathrm{SD}^{*}\end{array}$ \\
\hline $\begin{array}{l}\text { Luleå } \\
\text { snow }\end{array}$ & $2000 \pm 170$ & $310 \pm 70$ & 7.1 & 21 & $66 \pm 0$ \\
\hline $\begin{array}{l}\text { Umeå } \\
\text { snow }\end{array}$ & $4800 \pm 470$ & $320 \pm 30$ & 6.7 & 180 & $725 \pm 5$ \\
\hline
\end{tabular}

* The concentrations correspond to 11 of meltwater from the initial homogenized snow samples

2017). In general, the concentrations in the Umeå snow were 3-4 times higher than in Luleå, and at both sites, metal concentrations could be arranged in a decreasing order as follows: $\mathrm{Zn}>\mathrm{Cu}>\mathrm{Pb}>\mathrm{Cd}$. As discussed later, the Umeå snow concentrations were greater than in Luleå as a result of greater TSS concentrations (4800 vs. $2000 \mathrm{mg} / \mathrm{l})$, in spite of lower traffic intensity $(17,800$ vs. 23,900 vehicles /day) in Umeå.

Dissolved metal concentrations varied from 0.01 to $61.3 \mu \mathrm{g} / \mathrm{l}$, with greater concentrations in Umeå samples for $\mathrm{Zn}$ and $\mathrm{Cd}$; $\mathrm{HM}$ dissolved concentrations were decreasing at both sites in the same order as the total metal concentrations: $\mathrm{Zn}>\mathrm{Cu}>\mathrm{Pb}>\mathrm{Cd}$. Dissolved $\mathrm{Pb}$ concentrations were below $1 \%$ of the total $\mathrm{Pb}$ values, and, therefore, truly dissolved concentrations of $\mathrm{Pb}$ were considered negligible and omitted from further discussion. Truly dissolved concentrations for the remaining three metals are listed in Table 3. It is worthwhile to note that between 71 and $98 \%$ of dissolved metal concentrations were attributed to the truly dissolved fraction. Hence, the studied HMs, $\mathrm{Cu}, \mathrm{Zn}$, and $\mathrm{Cd}$ are present either in the truly dissolved fraction $(<3000 \mathrm{MWCO})$ or in the particulate fraction $(>0.45 \mu \mathrm{m})$. The colloidal fraction, which falls between 3000 MWCO (approximately $0.0024 \mu \mathrm{m}$ (Yoon 2016)) and $0.45 \mu \mathrm{m}$, was very small.

The snowmelt from the initial homogenized snow samples was also analysed for 16 PAHs prioritised by the US EPA, but only the selected ones are presented individually in this paper; the others are just included in various PAH groups. The PAHs selection was based on their concentrations in the initial homogenized snow samples, environmental significance, and recommendations from the literature. Table 4 shows the concentrations of the selected PAHs, the sum of 16 PAHs (sum 16), sum of seven carcinogenic PAHS

Table 3 Concentrations of heavy metals in the homogenized (initial) snow samples from Luleå and Umeå

\begin{tabular}{|c|c|c|c|c|}
\hline & $\mathrm{Pb}$ mean $\pm \mathrm{SD}^{\mathrm{a}}$ & $\mathrm{Cu}$ mean $\pm \mathrm{SD}$ & $\mathrm{Zn}$ mean $\pm \mathrm{SD}$ & $\mathrm{Cd}$ mean $\pm \mathrm{SD}$ \\
\hline \multicolumn{5}{|l|}{ Luleå sample } \\
\hline Total $(\mu \mathrm{g} / \mathrm{l})$ & $41.9 \pm 3.8$ & $303 \pm 35.9$ & $817 \pm 112$ & $0.43 \pm 0.05$ \\
\hline Dissolved $(\mu \mathrm{g} / \mathrm{l})$ & $0.14 \pm 0.01$ & $20.7 \pm 0.25$ & $28.6 \pm 0.86$ & $0.01 \pm 0.001$ \\
\hline Truly dissolved $(\mu \mathrm{g} / \mathrm{l})$ & $--^{b}$ & $14.7^{\mathrm{c}}$ & $21.5^{\mathrm{c}}$ & 0.01 \\
\hline Diss/Tot (\%) & 0.3 & 6.9 & 3.5 & 2.4 \\
\hline Truly diss/Diss (\%) & $---{ }^{b}$ & 71 & 75 & 90 \\
\hline \multicolumn{5}{|l|}{ Umeå sample } \\
\hline Total $(\mu \mathrm{g} / \mathrm{l})$ & $165 \pm 7$ & $905 \pm 16.6$ & $3150 \pm 0$ & $1.87 \pm 0.13$ \\
\hline Dissolved ( $\mu \mathrm{g} / \mathrm{l})$ & $0.011 \pm 0.001$ & $6.08 \pm 0.355$ & $61.3 \pm 3.64$ & $0.058 \pm 0.005$ \\
\hline Truly dissolved $(\mu \mathrm{g} / \mathrm{l})$ & $---{ }^{b}$ & $4.5^{\mathrm{c}}$ & $57.9^{c}$ & 0.06 \\
\hline Diss/Tot (\%) & 0.007 & 0.67 & 1.9 & 3.1 \\
\hline Truly diss/Diss (\%) & $--{ }^{b}$ & 74 & 94 & 98 \\
\hline
\end{tabular}

${ }^{a} \mathrm{SD}$ the standard deviation from three measurements $(N=3)$

${ }^{\mathrm{b}}$ The dissolved concentrations of $\mathrm{Pb}$ were less than $1 \%$; hence the truly dissolved fraction was assumed to be absent

${ }^{\mathrm{c}}$ Ultrafiltered $\mathrm{Zn}$ and $\mathrm{Cu}$ were detected in blank samples at 1.43 and $0.50 \mu \mathrm{g} / \mathrm{l}$, respectively. These values were subtracted from the measured concentrations of truly dissolved concentrations of $\mathrm{Zn}$ and $\mathrm{Cu}$ 
Table 4 Concentrations of the selected PAHs: sum of 16 PAHs, sum of carcinogenic PAHs, and sums of LMW, MMW, and HMW-PAHs in the initial homogenized snow samples from Luleå and Umeå

*Mean \pm standard deviation

\begin{tabular}{lcc}
\hline PAHs & $\begin{array}{c}\text { Initial snow_Luleå } \\
(\mu \mathrm{g} / \mathrm{l})\end{array}$ & $\begin{array}{c}\text { Initial snow-Umeå } \\
(\mu \mathrm{g} / \mathrm{l})\end{array}$ \\
\hline Nap (LMW) & $0.06 \pm 0.02^{*}$ & $0.08 \pm 0.03$ \\
Phe (MMW) & $0.41 \pm 0.11$ & $1.26 \pm 0.33$ \\
Flt (MMW) & $0.49 \pm 0.15$ & $1.76 \pm 0.55$ \\
Pyr (MMW) & $0.58 \pm 0.18$ & $2.31 \pm 0.72$ \\
BbF (HMW \& Carc) & $0.27 \pm 0.10$ & $1.1 \pm 0.41$ \\
BghiP (HMW) & $0.21 \pm 0.09$ & $0.8 \pm 0.32$ \\
IndP (HMW\& Carc) & $0.13 \pm 0.04$ & $0.37 \pm 0.131$ \\
Sum of 16 USEPA PAHs & $2.72 \pm 0.85$ & $9.64 \pm 3.03$ \\
Sum Carc & $0.88 \pm 0.28$ & $3.24 \pm 1.05$ \\
Sum LMW-PAHs & $0.09 \pm 0.03$ & $0.14 \pm 0.04$ \\
Sum MMW-PAHs & $1.54 \pm 0.45$ & $5.46 \pm 1.62$ \\
Sum HMW-PAHs & $1.09 \pm 0.37$ & $4.04 \pm 1.37$ \\
\hline
\end{tabular}

(Chr, Bbf, Bkf, Bap, IndP, DahA, and BaA; sum carc), sum of lower molecular weight PAHS (LMW-PAHs), sum of medium molecular weight PAHs (MMWPAHs), and sum of high molecular weight PAHs (HMW-PAHs) in the homogenized initial snow samples from Luleå and Umeå.

The individual PAH concentrations in the initial snow varied from 0.06 to $0.58 \mu \mathrm{g} / 1$ in Luleå and 0.08 to $2.31 \mu \mathrm{g} / 1$ in Umeå, with Nap occurring at the lowest and Pyr at the highest concentrations among the 16 PAHs in both samples. Typically, the concentrations of PAHs were about 3 to 4 times higher in the Umeå sample, compared with the Luleå sample, except for Nap occurring at similar concentrations at both locations. Flt and Pyr concentrations were also reported in the

Average L1- L3

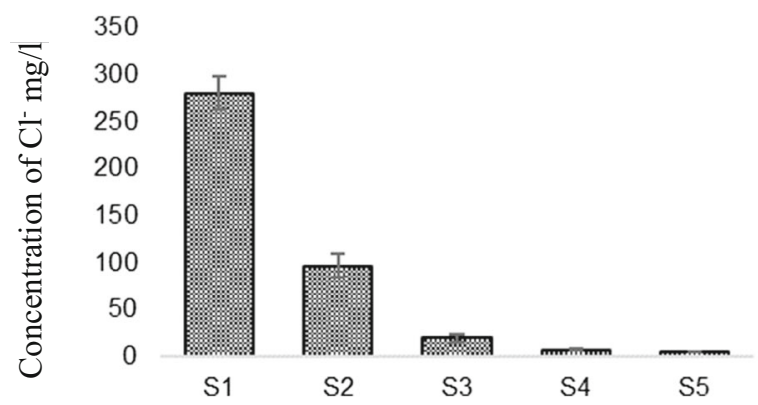

dissolved fraction, but very close to the reporting limit. As expected, PAHs in the initial snow samples were strongly particulate bound, with dissolved concentrations below the reporting limit in both initial homogenized snow samples.

\subsection{Controlled Melting of Laboratory Snow Piles}

The three replica piles made of Luleå snow, without salt added, were labelled L1-L3 and those from Umeå, with salt added, were labelled U1-U3. The average time needed by L1-L3 to fully melt was $94 \mathrm{~h}$ and that for U1-U3 was $70 \mathrm{~h}$ (without the warming up time). Thus, the piles with added salt melted 1.3 times faster than those without salt. Figure 5 shows the average concentrations of chlorides, and Fig. 6 shows the average concentrations of

S1-S5- sequential numbering of 1.5 L snowmelt samples

Error bars indicate the standard deviation of concentrations of chlorides in corresponding samples.

Fig. 5 Chloride concentrations, in sequential meltwater samples, averaged for triplicate snow piles L1-3 and U1-3, respectively.

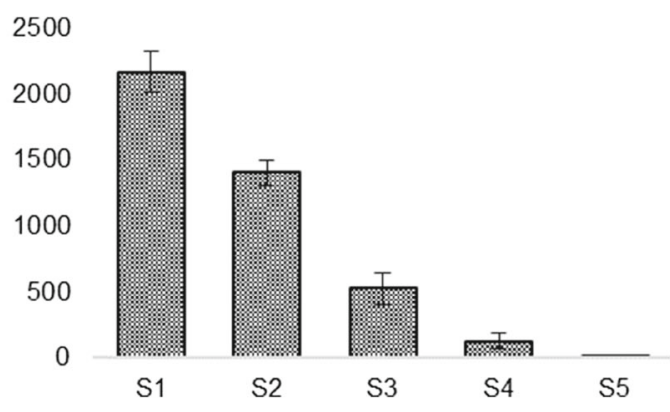


Average - L1-L3
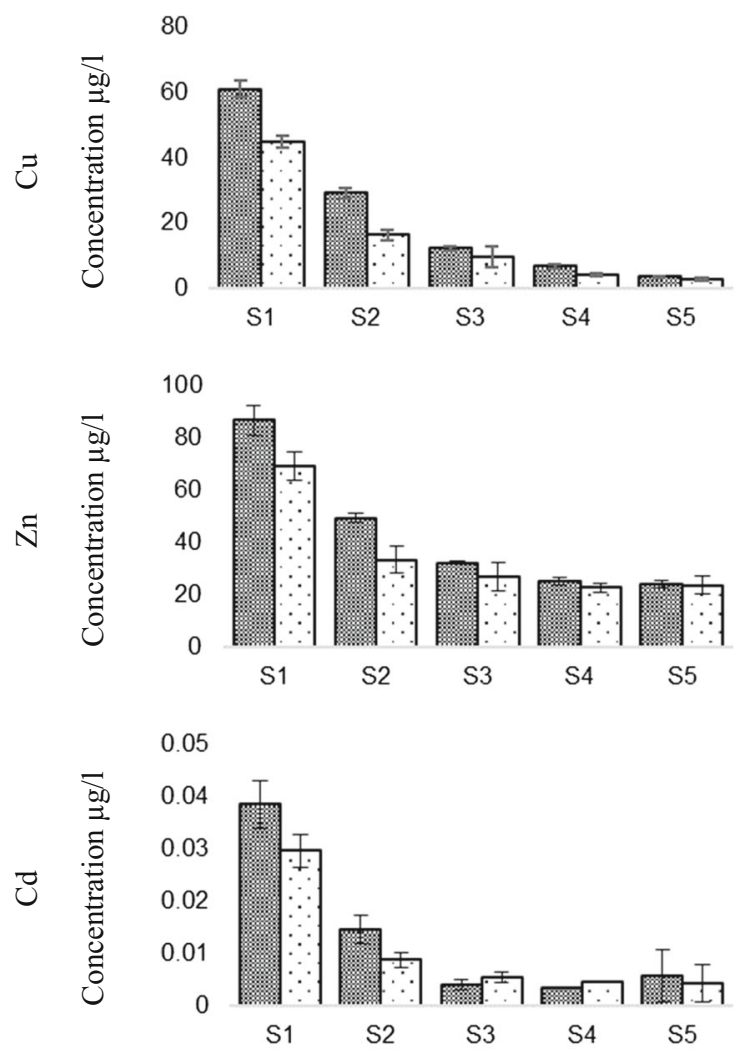

Average - U1-U3
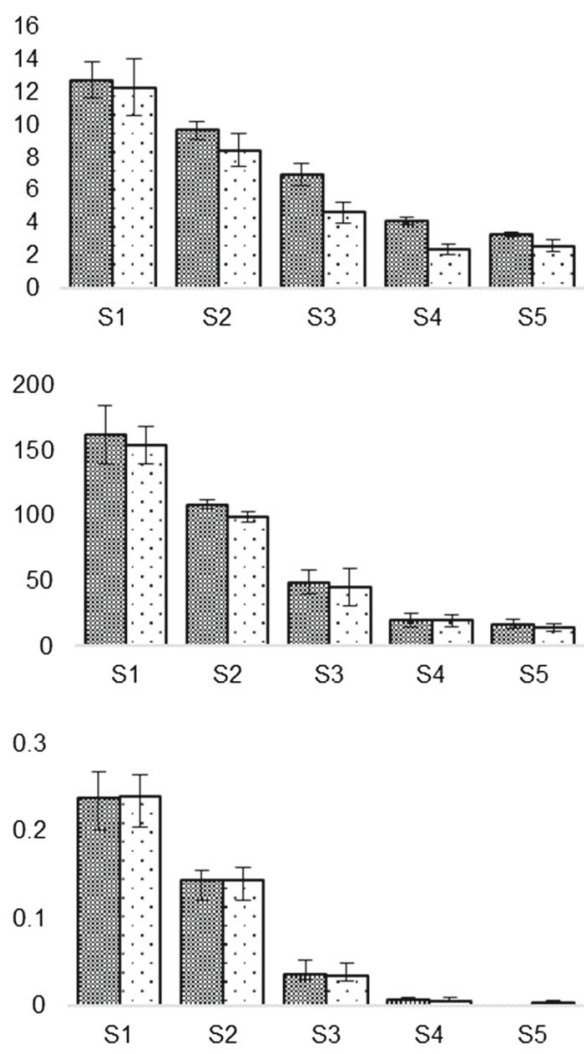

Dissolved $\square$ Truly dissolved

S1-S5- sequential numbering of 1.5 L snowmelt samples

Error bars indicate the standard deviation of concentrations of metals in corresponding samples

Fig. 6 Dissolved and truly dissolved $\mathrm{Zn}, \mathrm{Cd}$, and $\mathrm{Cu}$ concentrations, in sequential meltwater samples, averaged for triplicate snow piles L13 and $\mathrm{U} 1-3$, respectively

dissolved and truly dissolved $\mathrm{Cu}, \mathrm{Zn}$, and $\mathrm{Cd}$ in the snowmelt samples from piles L1-L3 and U1-U3, calculated from measurements for individual piles. Advanced release or preferential elution of chlorides was clearly detected in all the piles. The dissolved and truly dissolved fractions of all the presented metals decreased in the meltwater from all the piles as snowmelt progressed, indicating early release of both dissolved fractions, in agreement with Colbeck (1981) and Schöndorf and Herrmann (1987). Release patterns for both sampled sites slightly differed, with the centroid of the total eluted mass of dissolved and truly dissolved HM arriving earlier in the Luleå melt sample, compared with that from Umeå. The highest concentrations were in the first snowmelt sample, which contained about $50 \%$ of the total flux of dissolved or truly dissolved HM. The percentages of truly dissolved to dissolved $\mathrm{Cu}, \mathrm{Zn}$, and $\mathrm{Cd}$ were higher in the meltwater from Umeå for the first two samples illustrating that the percentage of truly dissolved to dissolved metals increased by application of salt. It reveals that the application of road salt increased the dissolved fraction of $\mathrm{Zn}, \mathrm{Cd}$, and $\mathrm{Cu}$ in the meltwater and the truly dissolved fraction was released early during the melt event. The concentrations of dissolved and truly dissolved metals in the first two meltwater samples from all the piles were higher than the corresponding concentrations of the initial snow samples indicating the early release of these fractions during the melting.

Table 5 shows the mass loads of total, dissolved, and truly dissolved HMs in the initial homogenized snow and 
Table 5 Mass loads $(\mu \mathrm{g})$ of total, dissolved, and truly dissolved metals in the initial snow and meltwater samples

\begin{tabular}{|c|c|c|c|c|c|c|c|c|c|}
\hline \multicolumn{2}{|r|}{ Metal } & \multicolumn{4}{|c|}{ Luleå } & \multicolumn{4}{|c|}{ Umeå } \\
\hline & & \multirow[t]{2}{*}{ Initial snow } & \multicolumn{3}{|c|}{ Melt water } & \multirow[t]{2}{*}{ Initial snow } & \multicolumn{3}{|c|}{ Melt water } \\
\hline & & & $\mathrm{L} 1$ & $\mathrm{~L} 2$ & L3 & & U1 & $\mathrm{U} 2$ & U3 \\
\hline \multirow[t]{3}{*}{$\mathrm{Cu}$} & Total $(\mu \mathrm{g})$ & $2724 \pm 323$ & 246 & 270 & 273 & $8148 \pm 149$ & 392 & 624 & 533 \\
\hline & Dissolved $(\mu \mathrm{g})$ & $186.6 \pm 2.26$ & 166 & 172 & 169 & $54.7 \pm 3.2$ & 57 & 55 & 59 \\
\hline & Truly Dissolved $(\mu \mathrm{g})$ & 132 & 108 & 110 & 120 & 41 & 39 & 43 & 46 \\
\hline \multirow[t]{3}{*}{$\mathrm{Zn}$} & Total $(\mu \mathrm{g})$ & $7356 \pm 1009$ & 620 & 658 & 695 & $28,350 \pm 0$ & 1808 & 2456 & 2288 \\
\hline & Dissolved $(\mu \mathrm{g})$ & $257 \pm 8$ & 329 & 340 & 334 & $552 \pm 32.7$ & 545 & 526 & 556 \\
\hline & Truly Dissolved $(\mu \mathrm{g})$ & 193 & 249 & 244 & 284 & 521 & 476 & 498 & 501 \\
\hline \multirow[t]{3}{*}{$\mathrm{Cd}$} & Total $(\mu \mathrm{g})$ & $3.83 \pm 0.44$ & 0.21 & 0.19 & 0.19 & $16.8 \pm 1.14$ & 0.89 & 1.29 & 1.02 \\
\hline & Dissolved $(\mu \mathrm{g})$ & $0.09 \pm 0.01$ & 0.11 & 0.1 & 0.09 & $0.52 \pm 0.04$ & 0.65 & 0.63 & 0.61 \\
\hline & Truly Dissolved $(\mu \mathrm{g})$ & 0.08 & 0.085 & 0.068 & 0.085 & 0.53 & 0.64 & 0.66 & 0.63 \\
\hline
\end{tabular}

meltwater samples, obtained by multiplying the meltwater volume by the concentration of each HM. Around $67 \%$ of the dissolved $\mathrm{Cu}$ was in truly dissolved form in meltwater from piles from Luleå and $75 \%$ for piles from Umeå. Seventy-eight percent and $91 \%$ of dissolved $\mathrm{Zn}$ were in a truly dissolved form in meltwater from piles from Luleå and Umeå, respectively, whereas $80 \%$ and $100 \%$ of dissolved Cd were in truly dissolved phase for meltwater from Luleå and Umeå samples. The higher ratio of truly dissolved metals to dissolved metals in the melt water from piles U1 to U3 cannot be attributed solely to the addition of salt to these piles, because some other characteristics of the snow samples from Umeå and Luleå also differed and may have contributed to this result. At this time, no literature data on this issue were found and confirmation of the above finding would require further experimentation with the same snow samples, some of which would be spiked with salt.

The release patterns of selected PAHs or groups of PAHs (Pyr, BbF, Sum 16 PAHS, Sum MMW PAHs, and Sum HMW PAHs) are shown in Fig. 7. Pyr, Flu, and Phe exhibit similar release patterns, so for brevity, only Pyr is shown in the figure. Similarly, BbF and BghiP showed similar patterns, so only BghiP was included in the figure. Average concentrations of PAHs in piles L1L3 displayed slightly elevated concentrations early during the melt event, but generally, the releases were fairly uniform. This somewhat anomalous result may be caused by very low PAH concentrations in these piles. A similar plot for piles U1-U3 showed slightly elevated concentrations in the first sample, but a clearly delayed release pattern with the highest concentrations occurring towards the end of the melt.
Cumulative percentages of total PAHs and TSS in the snowmelt are shown in Fig. 8 by plotting the relative cumulative constituent flux vs. the relative cumulative snowmelt flux. In these plots, a $45^{\circ}$ line represents a constant concentration throughout the event; plots above this line indicate an advanced constituent release, plots below the line indicate delayed release pattern. The plots in Fig. 8 include the sum of 16 PAHs, sum of MMW PAHs, sum of HMW PAHs, and TSS. Among piles L1-L3, L1 indicated an advanced pattern in the case of TSS and the sums of PAHs, L2 produced a slightly advanced pattern of the sums of PAHs and more or less a constant release of TSS, and finally, L3 produced uniform releases of both TSS and sums of PAHs. In all three cases, the peak concentrations of the sums of PAHs (i.e. the steepest gradient between two neighbouring points on the mass plot) were noted at the start of the melt event. This somewhat anomalous result may have been caused by very low PAH concentrations in these piles and by plotting sums of PAHs, rather than individual substances; the more soluble substances in the group will elute early and may distort the release pattern of the group. Furthermore, L1 melting may have been also affected by the pile location close to the door of the climate room; the door was opened many times during the experiment to take out samples and, consequently, this pile melted faster, compared with L2 and L3. Such disruptions may have affected the release of pollutants from L1 and perhaps contributed to advanced releases of PAHs and TSS from L1. Both PAHs and TSS from U1-U3 showed a delayed release pattern, with increasing concentrations in late parts of the melt event. 

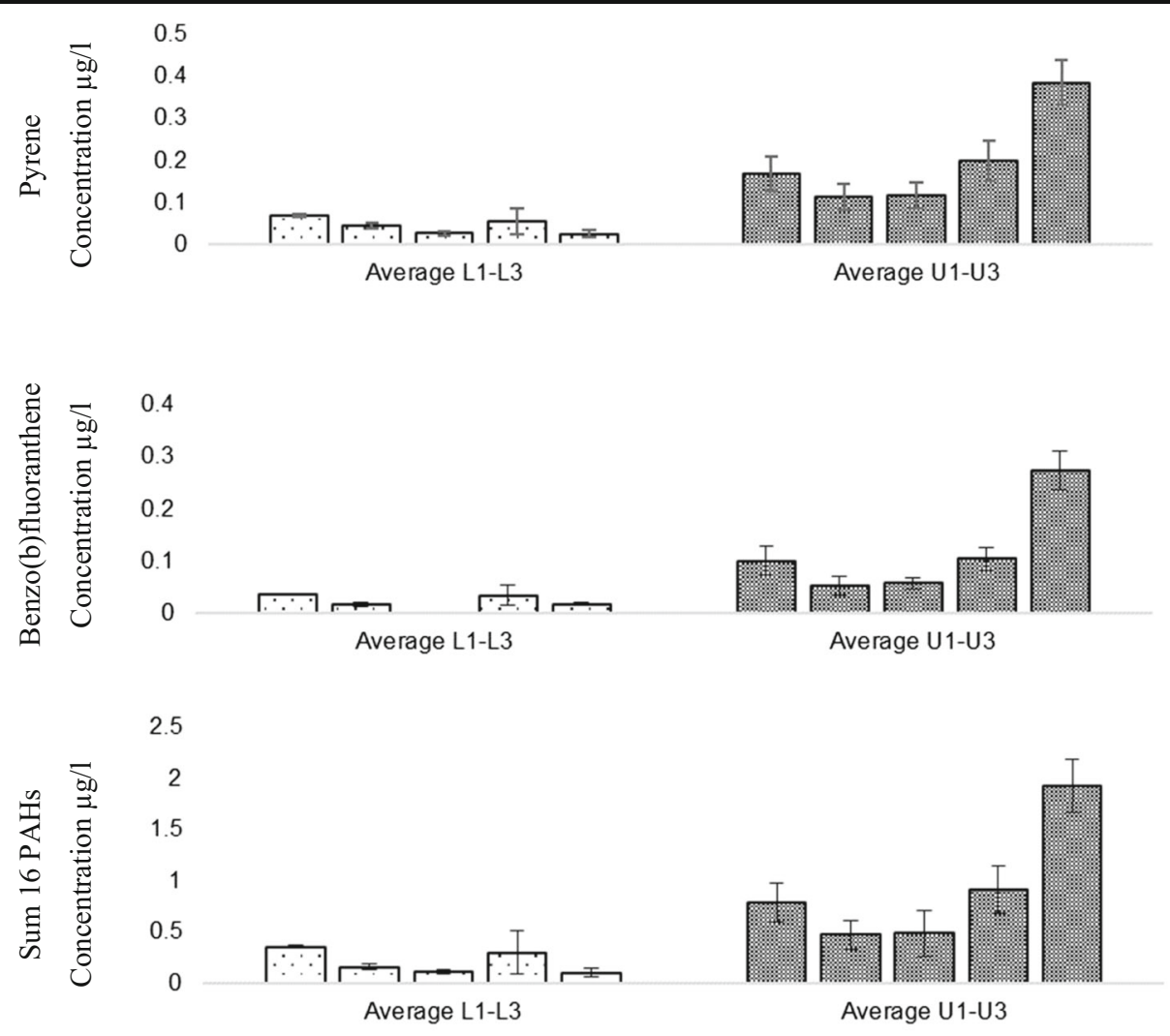

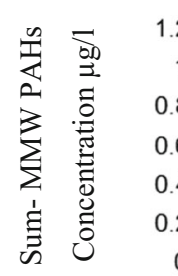

\section{2}

1

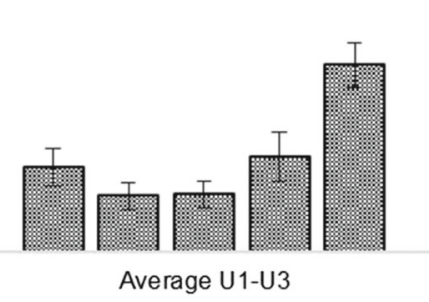

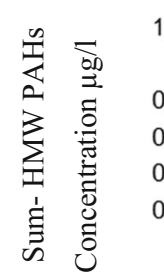

1.2
1
0.8
0.6
0.4
0.2
0
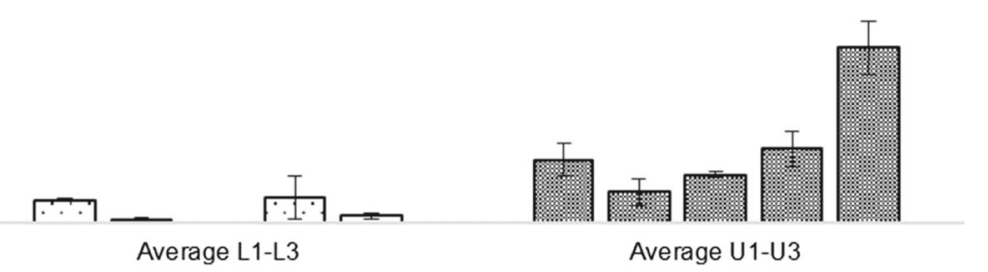

The five bars represent five meltwater sample (S1, S2, S3, S4 and S5) from the corresponding piles. The error bars indicate Standard deviation concentrations of PAHs of samples from the corresponding piles.

Fig. 7 PAH concentrations, in sequential meltwater samples, averaged for triplicate snow piles L1-3 and U1-3, respectively 
L1

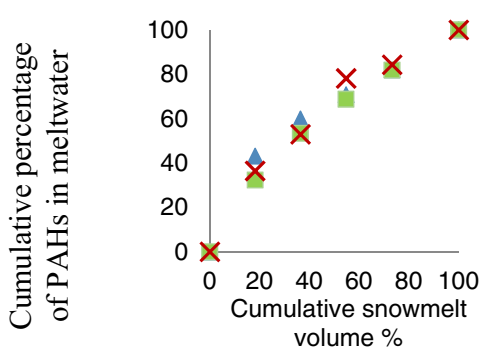

U1

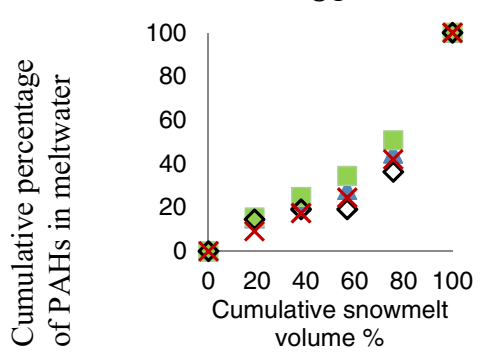

L2

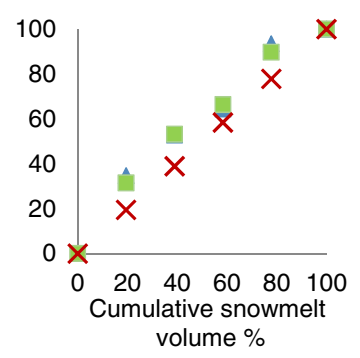

$\mathrm{U} 2$

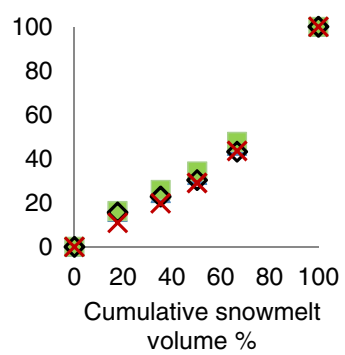

L3

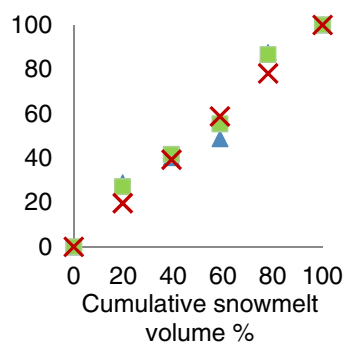

$\mathrm{U} 3$

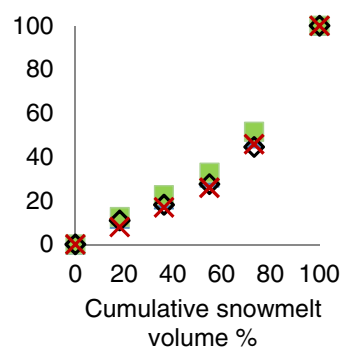

Sum of 16 PAHs $\triangle$, Sum of MMW PAHs $\square$, Sum of HMW PAHS $\diamond$, TSS $\mathbf{X}$

Fig. 8 Cumulative total PAHs and TSS loads (\%) vs. cumulative snowmelt volume (\%)

The sum of 16 PAHs followed the same release pattern as suspended solids in meltwater for all the piles, confirming that PAHs were particulate bound in snowmelt samples. The LMW-PAHs were present only in the first two meltwater samples but were below the reporting limits in the rest of the meltwater samples. Consequently, their cumulative mass curves are not shown. For L1-L3, the HMW-PAHs (they are the same as carcinogenic PAHs) showed irregular release patterns. In most of the meltwater samples, the HMW-PAHs concentrations were less than, or close to, the reporting limit, so the HMWPAHs for L1-L3 were not presented.

The sediment residues left on the base plate after the melting finished were analysed for PAHs. The mass loads of different PAHs in the initial snow, meltwater, and sediment residue are given in Table 6 . The average percentages of PAHs transported with the melt water, compared with the PAH mass in the initial snow samples, were below $12 \%$ as shown in Table 6. The percentage of PAHs transported with meltwater was higher for piles with added salt. The remaining PAH loads $(88 \%)$ were particulate bound. The percentage recoveries of the PAHs mass in the melting experiments were calculated by dividing the substance yield from melting experiments (i.e. adding the substance masses in the melt water and in the sediment residue) and dividing it by the substance mass in the initial snow samples. The average PAH recoveries from piles U1-U3 were about 114\%, but for piles L1-L3 from Luleå, such recoveries were on average $206 \%$, indicating that the PAH content in the initial snow was underestimated. The resulting anomalies were explained by very low PAH concentrations in the initial snow samples, with most of the PAHs concentrations in meltwater samples below the reporting limit, and possible sampling bias when extracting the initial snow sample from the snow homogenized in the laboratory.

\section{Discussion}

4.1 Occurrence and Partitioning of Metals and PAHs in Roadside Snow and Snowmelt

Reinosdotter and Viklander (2005) studied the snow quality in two Swedish municipalities and reported the total HM concentrations in snow along a high traffic road in Luleå (AADT $=21,900$ vehicles/day) as $\mathrm{Cu}=626 \pm$ $996 \mu \mathrm{g} / \mathrm{l}, \mathrm{Pb}=130 \pm 181 \mu \mathrm{g} / \mathrm{l}$, and $\mathrm{Zn}=1256 \pm 1673 \mu \mathrm{g} /$ 1 , which are comparable to those reported in the current 
Table 6 Mass loads of PAHs in the initial snow, meltwater, and sediment samples

\begin{tabular}{|c|c|c|c|c|c|c|c|}
\hline & & Pyr & $\mathrm{BaP}$ & PAH, sum 16 & Carcinogenic PAH & PAH, sum MMW & PAH, sum HMW \\
\hline \multicolumn{2}{|c|}{ PAHs in the initial snow-Luleå $(\mu \mathrm{g})$} & 5.3 & 1.4 & 24.5 & 7.9 & 13.9 & 9.8 \\
\hline \multirow[t]{2}{*}{ L1 } & PAHs in meltwater & 0.28 & 0.05 & 1.68 & 0.45 & 0.91 & 0.54 \\
\hline & PAHs in sediment & 9 & 2.5 & 51 & 17.8 & 26.2 & 23.4 \\
\hline \multirow[t]{2}{*}{ L2 } & PAHs in meltwater & 0.33 & 0.08 & 1.56 & 0.38 & 0.98 & 0.46 \\
\hline & PAHs in sediment & 8.3 & 2.4 & 49 & 16.2 & 25.4 & 21.2 \\
\hline \multirow[t]{2}{*}{ L3 } & PAHs in meltwater & 0.39 & 0.09 & 1.91 & 0.53 & 1.17 & 0.66 \\
\hline & PAHs in sediment & 7.9 & 2.3 & 42.8 & 15.0 & 21.7 & 20 \\
\hline \multirow[t]{2}{*}{ Average L1-L3 } & $\%$ of PAHs in meltwater & 6 & 5 & 7 & 6 & 7 & 6 \\
\hline & $\%$ recovery & $165^{*}$ & $177^{*}$ & $201 *$ & $212^{*}$ & $183 *$ & $225^{*}$ \\
\hline \multicolumn{2}{|c|}{ PAHs in the initial snow-Umeå ( $\mu \mathrm{g})$} & 20.8 & 4.5 & 86.7 & 29.2 & 49.1 & 36.4 \\
\hline \multirow[t]{2}{*}{ U1 } & PAHs in meltwater & 1.1 & 0.4 & 6.1 & 2.2 & 3.4 & 2.7 \\
\hline & PAHs in sediment & 21.9 & 4.0 & 102.4 & 34.8 & 52.9 & 47.6 \\
\hline \multirow[t]{2}{*}{$\mathrm{U} 2$} & PAHs in meltwater & 2.0 & 0.6 & 9.3 & 3.5 & 5.0 & 4.3 \\
\hline & PAHs in sediment & 20.3 & 3.6 & 88.1 & 29.8 & 46.6 & 40.0 \\
\hline \multirow[t]{2}{*}{$\mathrm{U} 3$} & PAHs in meltwater & 2.0 & 0.6 & 9.6 & 3.7 & 5.0 & 4.5 \\
\hline & PAHs in sediment & 18.9 & 4.1 & 89.3 & 32.3 & 45.3 & 42.5 \\
\hline \multirow[t]{2}{*}{ Average U1-U3 } & $\%$ of PAHs in meltwater & 8 & 12 & 10 & 11 & 9 & 11 \\
\hline & $\%$ recovery & 106 & 99 & 117 & 121 & 107 & 130 \\
\hline
\end{tabular}

*The percentage recoveries of PAHs from Luleå samples exceed 100 because of low PAH concentrations in the initial snow sample

study for the Luleå and Umeå sites. In general, these high concentrations indicate long periods of metal accumulations in roadside snowbanks. Even though both sites had similar traffic intensities, snow samples from Umeå contained more suspended particles than those from Luleå, which was probably given by the $2-4$ times smaller volume of the snowbank in the former location, per unit length. Hence, for similar influx rates of TSS into both snowbanks, the one in Umeå should indicate higher TSS concentrations. The higher electrical conductivity and chloride concentrations of the samples from Umeå were caused partly by road salting and partly by the addition of commercial salt during the mixing of snow.

Concerning the partitioning of heavy metals and PAHs in snow, the constituents in both groups are mostly particulate bound (Glenn and Sansalone 2002; Reinosdotter et al. 2006; Meyer et al. 2011). Moghadas et al. (2015) studied the accumulation of metals in urban snow and found a good correlation between the concentrations of metals and TSS. In our study, high TSS concentrations also explained the high concentrations of metals in the Umeå samples. The order of the concentration magnitudes of total $\mathrm{HM}(\mathrm{Zn}>\mathrm{Cu}>\mathrm{Pb}>\mathrm{Cd})$ was in agreement with the findings of Vasić et al. (2012) and Moghadas et al. (2015). Warren and Zimmerman (1994) studied the influence of $\mathrm{NaCl}$ on the partitioning of $\mathrm{Cu}, \mathrm{Zn}$, and $\mathrm{Cd}$ to particulate and dissolved fractions in riverine water. They found that $\mathrm{NaCl}$ was an important factor in metal partitioning and increasing $\mathrm{NaCl}$ concentrations in the Don River increased the partitioning of the studied metals from the particulate to the dissolved fraction. Novotny et al. (1998) investigated the relationship between the metal partitioning coefficient and salinity in snowmelt and concluded the same. Contrarily to these findings, the dissolved concentrations of $\mathrm{Cu}$ and $\mathrm{Zn}$ in the Umeå initial snow samples with added salt represented smaller fractions of the total metal concentrations than those for the Luleå samples without salt added. However, because of other differences between both sample sets characteristics, this effect cannot be attributed to the salt presence only. Also, on the sampling day and the day before, in Umeå, the temperature was above zero and the snow was melting. An early release of dissolved substances from the snowpack may have lowered the dissolved to total percentage of $\mathrm{Cu}$ and $\mathrm{Zn}$ in the samples from Umeå, compared with those Luleå.

All the metals analysed for the truly dissolved fraction showed that more than $65 \%$ of the metals in the fraction smaller than $0.45 \mu \mathrm{m}$ were actually smaller than 3000 MWCO (approximately $0.0024 \mu \mathrm{m}$ ). No conclusions 
could be drawn for the dissolved concentrations of $\mathrm{Cd}$, which were rather small and close to the reporting limit in the meltwater samples. The percentage of the truly dissolved fraction can be described in the following descending order: $\mathrm{Zn}>\mathrm{Cu}$ for meltwater from all the snow piles.

Luan and Vadas (2015) studied the size distribution of particulate attached metals in stormwater, treated wastewater effluent and stream water, and found that more than $50 \%$ of the dissolved $(<0.45 \mu \mathrm{m}) \mathrm{Zn}$ and $\mathrm{Cu}$ were truly dissolved $(<0.3 \mathrm{kDa})$ in the wastewater effluent and stormwater runoff samples. Guéguen and Dominik (2003) investigated the partitioning of $\mathrm{Co}, \mathrm{Cu}$, $\mathrm{Cr}, \mathrm{Mn}$, and $\mathrm{Zn}$ among the particulate $(>1.2 \mu \mathrm{m})$, colloidal $(1.2 \mu \mathrm{m}$ to $1 \mathrm{kDa})$, and truly dissolved $(<1 \mathrm{kDa})$ fractions in river water samples. For the reference sample, the percentage of truly dissolved to dissolved fraction was $67 \%$ for $\mathrm{Cu}$ and $88 \%$ for $\mathrm{Zn}$. For the river water polluted by coalmine effluents, these percentages were 93 and $99 \%$ for $\mathrm{Cu}$ and $\mathrm{Zn}$, respectively.

One of the reasons for varying percentages of truly dissolved to dissolved fractions of metals reported in the literature is the use of different cut-off limits for dissolved and truly dissolved fractions and different types and characteristics of samples studied by various authors. However, in all the references studied, more than $50 \%$ of the dissolved fraction was actually in the truly dissolved form. The percentage of truly dissolved to dissolved fractions of metals was higher in our study, compared with Luan and Vadas (2015) findings, since they used a smaller size membrane $(0.3 \mathrm{kDa}$ vs. $3 \mathrm{kDa})$ for ultrafiltration. In agreement with the findings of Guéguen and Dominik (2003), the truly dissolved to dissolved fractions were higher for $\mathrm{Zn}$ than $\mathrm{Cu}$ in the initial snow and meltwater samples in this study.

\subsection{Release of Pollutants from Snowpacks}

A number of researchers studied the early release of the dissolved fraction during the snowmelt (Schöndorf and Herrmann 1987; Viklander 1997; Oberts et al. 2000; Meyer et al. 2009b). In this study, the advanced release, or preferential elution, was noted for both dissolved and truly dissolved metals. The preferential elution of dissolved and truly dissolved $\mathrm{Zn}$ was faster in the meltwater from the Umeå piles, to which salt was added. For $\mathrm{Cu}$, the preferential elution was higher in the piles from Luleå, possibly because of very low concentrations of dissolved $\mathrm{Cu}$ in the Umeå samples. The concentrations of dissolved and truly dissolved metals in the first two samples of meltwater were higher than the corresponding concentrations in the initial snow. During spring, when the first snowmelt occurs, meltwater carries the heavy metals in these bioavailable forms and delivers them to the receiving waterbodies. Thus, the urban meltwater may cause a threat to aquatic life (Reader et al. 1989; Reader and Dempsey 1989).

The percentages of truly dissolved to dissolved metal concentrations were higher in snowmelt from piles with added salt, suggesting that application of salt may contribute to increases in the truly dissolved fraction of metals and thereby make those metals more bioavailable for aquatic organisms. Millions of tonnes of salt are applied each winter in cool temperate climate countries as de-icers improving the mobility and traffic safety (Venner and Zeimer 2004). Such salt increases the conductivity, salinity, and chloride concentrations in meltwater (Xue et al. 2015) and also the dissolved and truly dissolved fractions of heavy metals. Releases of chloride from a melting snow pack follow the preferential elution (Exall et al. 2011; Westerlund and Viklander 2011) and may cause toxic shocks to the aquatic life in the receiving waterbodies (Novotny et al. 1998). Thus, controls of applications of road salt are important for limiting the impact of urban snowmelt on the aquatic environment.

The PAHs in the meltwater from U1-U3 piles showed a delayed release. Meyer et al. (2009b) studied the temporal variation of different PAHs and the effect of chemical partitioning on the release of PAHs from an artificial snowpack spiked with target pollutants. They found that the melting snowpack acted as a filter trapping particles in snow, and hydrophobic chemicals, like PAHs, were released at the end of the melt event (Meyer et al. 2009b). This supports the observed delayed releases of PAHs from U1-U3. The HMW-PAHs followed the same pattern as suspended solids in U1-U3, reflecting their strong association with suspended particles. Meyer et al. (2011) concluded the same by studying PAHs in river water samples during two snowmelt periods in 2007 and 2008. The concentrations of HMWPAHs were below the reporting limit in some of the meltwater samples from L1-L3, and this could be the reason for irregular releases of HMW-PAHs from these piles. Among the LMW-PAHs, concentrations of Acy were below the reporting limit in all meltwater samples and Nap and Ace were released early during the melt event for all the piles, which agreed with their relatively high solubility. Meyer et al. (2009a) also reported an advanced release of Nap. Even though PAHs have very 
low aqueous solubility (Choi et al. 2010), the solubility of individual substances increases with their decreasing molecular weight (Abdel-Shafy and Mansour 2016). Consequently, the relatively high solubility of LMWPAHs led to the early releases of Ace and Nap from the snow piles studied.

The analysis of sediment residue from melting piles revealed that more than $85 \%$ of the PAHs content in the snow stayed in the residue for all the snow piles. The percentage of PAHs in the meltwater was higher in piles from Umeå. Meyer et al. (2011) investigated the transport of nine PAHs (Phe, Ant, Flu, Pyr, BbF, BkF, BaP, IndP, and BghiP) during a snowmelt event in a catchment and reported that they were strongly associated with suspended particles. Reinosdotter and Viklander (2007) studied the effect of road salt on the release of different pollutants from urban snow and reported that the amount of particles and metals in the meltwater increased with salt applications. Both these results imply that the higher rate of release of PAHs in the samples from Umeå is due to the presence of salt in these samples. Another reason for lower rate of transportation of PAHs from Luleå samples can be the lower concentrations in the initial snow sample from Luleå, even though Westerlund et al. (2011) found that the release of particles from melting snow did not depend on the initial concentration of the particles.

\subsection{Environmental Significance of Snowmelt and Sediments Released from Roadside Snow}

A direct assessment of the collected snow/snowmelt quality data in the context of the existing water quality regulations or guidelines for receiving waters is not feasible, because our data represent episodic samples collected in upstream reaches of the respective urban catchments. To reach the receiving waters, the chemicals released from snowbanks would need to travel from the point of release to the receiving waters, or be disposed with snow in open waters (where permitted) or preferably in snow storage and treatment facilities. In the conditions of the two cities studied, the overland route would start with roadside ditches draining into sewer inlets and continue with storm sewers discharging to the receiving waters. Along this route, there would be ample opportunities for passive treatment of snowmelt runoff, mostly by sedimentation and infiltration in the ditches (Viklander 1999; Westerlund et al. 2011). In such processes, a significant part of the chemical burden conveyed by runoff would get incorporated into drainage ditch soils and the main environmental concerns would be the soil quality for protection of environmental and human health. However, one could also argue that drainage ditch soils have a limited infiltration capacity in early spring and then the resulting runoff would have adequate transport capacity to convey some part of snowmelt with fine solids to the receiving waters. This second scenario was addressed by Bartlett et al. (2012a,b), who reported toxic effects in a pond receiving urban snowmelt from a highway with high ADT (average daily traffic). The direct disposal of relatively fresh snow in open waters is controlled by Swedish environmental regulations, and the snowmelt pollution data presented herein support the need for such controls.

Over the last decade, Swedish municipalities made an effort to develop annual stormwater effluent quality guidelines for some metals (Table 7). Notwithstanding the differences between the basis for these guidelines and the data collected in this study, it is of interest and

Table 7 Stormwater quality guidelines proposed for heavy metals and the corresponding mean concentrations in melted snow samples from Luleå and Umeå

\begin{tabular}{|c|c|c|c|c|}
\hline \multirow[t]{2}{*}{ Chemical } & \multicolumn{2}{|c|}{$\begin{array}{l}\text { Annual average stormwater effluent } \\
\text { quality }(\mu \mathrm{g} / \mathrm{l})\end{array}$} & \multirow{2}{*}{$\begin{array}{l}\text { Concentration in } \\
\text { snow samples from } \\
\text { Luleå }(\mu \mathrm{g} / \mathrm{l})\end{array}$} & \multirow{2}{*}{$\begin{array}{l}\text { Concentration in } \\
\text { snow samples from } \\
\text { Umeå }(\mu \mathrm{g} / \mathrm{l})\end{array}$} \\
\hline & Alm et al. 2010 & City of Goteborg & & \\
\hline Cd Tot & 0.45 & 0.4 & 0.43 & 1.87 \\
\hline $\mathrm{Cu}$ Tot & 30 & 10 & 303 & 905 \\
\hline Ni Tot & 20 & 40 & - & - \\
\hline $\mathrm{Pb}$ Tot & 10 & 14 & 41.9 & 165 \\
\hline Zn Tot & 90 & 30 & 817 & 3150 \\
\hline
\end{tabular}


concern to note that mean snowmelt concentrations exceeded the guidelines by one to two orders of magnitude, in the case of $\mathrm{Cu}, \mathrm{Pb}$, and $\mathrm{Zn}$.

The disposal of used snow in snow storage and treatment facilities is another option for snow disposal, particularly in more developed urban areas (Exall et al. 2011). In such facilities, snow is stored on a melting pad and allowed to melt. Snowmelt leaving the pad is collected and discharged into a pond for further treatment, mostly by settling. Recognizing that more than $90 \%$ of metals and PAHs were in particulate fractions, and the water release from snow is a relatively slow process, settling should be effective in removing both groups of pollutants.

\subsection{Practical Implications}

Information produced in this study has practical implications for addressing snow disposal and the treatment of snowmelt from permanent snow storage facilities (Exall et al. 2011). Firstly, pollutants (in our case metals and PAHs) accumulate in snowbanks and towards the end of winter reach concentrations highly exceeding those in stormwater runoff; for example, for TSS, and total $\mathrm{Cu}$ and $\mathrm{Zn}$, the mean concentrations in snow samples exceeded those in the US NURP data base for urban runoff from a median urban site (USEPA 1983) 5 to 48 times. Furthermore, pollutant release concentrations vary depending on the pollutant solubility. Dissolved pollutants, e.g. chloride, or dissolved metals, are eluted early during the final melt, or even during smaller intermittent melts, and hydrophobic pollutants (e.g. most PAHs) leave snow rather late in the melting process, or stay on ground in residue. In spite of high concentrations of trace metals and PAHs in urban snowmelt, only a small fraction of urban snowmelt is treated, because of inefficiencies in dealing with diffuse snow pollution distributed over large areas. The fraction that is treated is usually the effluent from specially designed snow storage sites, which may incorporate a stormwater storage and treatment, mostly in the form of settling (Droste and Johnston 1993) and passage through a wetland (Exall et al. 2011). Other control measures would be source controls, reducing the input of pollutants into the snow. Such programs exist, e.g. concerning road salt usage (Stone and Marsalek, 2011) and substitution of less environmentally harmful materials in car manufacturing and operation.

\section{Conclusions}

Laboratory snow melting experiments were conducted with actual late-winter snow samples from two similar northern Swedish cities to advance the understanding of releases of the selected heavy metals $(\mathrm{Cu}, \mathrm{Pb}, \mathrm{Zn}$, and $\mathrm{Cd})$ and PAHs from melting snow. Metal concentrations were determined in three fractions: total, dissolved, and truly dissolved (defined as the fraction passing through a 3-kDa ultrafilter). Total metal concentrations in snowmelt were relatively high and correlated with high TSS concentrations (2000 and $4800 \mathrm{mg} / \mathrm{l}$, in Luleå and Umeå, respectively): in Luleå samples, $\mathrm{Cd}=0.43 ; \mathrm{Cu}=303 ; \mathrm{Pb}=41.9 ;$ and $\mathrm{Zn}=817$ and in Umeå samples, $\mathrm{Cd}=1.87 ; \mathrm{Cu}=905 ; \mathrm{Pb}=165$; and $\mathrm{Zn}=3150$ (all in $\mu \mathrm{g} / \mathrm{l}$ ). These high concentrations resulted from long-term (almost 5 months) accumulation of pollutants and polluted TSS in snowbanks along urban roads. Compared with total concentrations, the dissolved metal concentrations were relatively small, at $0.3-6.9 \%$ of total concentrations in Luleå and $0.01-3.1 \%$ in Umeå, but were of significant magnitude, with the exception of $\mathrm{Pb}$. The truly dissolved fraction of metals, which is a new finding in snowmelt studies, represented $71-90 \%$ of the dissolved fraction in Lulea and $74-98 \%$ in Umeå. Dissolved pollutant fractions in both cities exhibited preferential elution from the laboratory snow piles. The PAHs studied (16 US EPA PAHs) were mostly particulate bound, with only $5-12 \%$ of the total burden contributed by the meltwater, and most dissolved concentrations below the reporting limits (except for Fluoranthene and Pyrene in the initial snow samples). PAH burdens in the Lulea samples were about one-third to one-fourth of those in Umeå. In general, the releases of PAHs from the snowpack were delayed and showed similar release patterns as TSS. The effects of salt addition on releases of metals and PAHs from laboratory snow piles were hard to discern, because of differences in snow characteristics from both locations (particularly TSS). Besides expanding the meagre data on HM and PAHs in roadside snow, contributions of new knowledge of this study include the finding that truly dissolved fractions of $\mathrm{Cd}, \mathrm{Cu}, \mathrm{Pb}$, and $\mathrm{Zn}$ represent high fraction (70-98\%) of the dissolved fraction, and PAHs releases from snow were not 
affected by salt (i.e. accelerated melting did not cause releases of solids with attached PAHs). The study produced new information on the pollution of late-winter roadside snow, just before final melting, fractionation of $\mathrm{HM}$ into truly dissolved fraction (representing more than $70 \%$ of the dissolved fraction), and limited effects of saltaccelerated snowmelt on flushing of PAHs attached to particles from the melting snow. The study results should be helpful for deciding on maximum age of removed snow which may be disposed of in open waters, with the older more polluted snow transported to snow storage/melting facilities, and on designing snowmelt treatment trains at such facilities.

Acknowledgements The authors wish to acknowledge the colleagues in the Urban Water Engineering group at the Luleå University of Technology for field and laboratory assistance.

Funding Information This work was funded by The Swedish Research Council Formas (Sustainable urban snow handling2015-00120).

Open Access This article is distributed under the terms of the Creative Commons Attribution 4.0 International License (http:// creativecommons.org/licenses/by/4.0/), which permits unrestricted use, distribution, and reproduction in any medium, provided you give appropriate credit to the original author(s) and the source, provide a link to the Creative Commons license, and indicate if changes were made.

\section{References}

Abdel-Shafy, H. I., \& Mansour, M. S. M. (2016). A review on polycyclic aromatic hydrocarbons: source, environmental impact, effect on human health and remediation. Egyptian Journal of Petroleum, 25, 107-123.

Alm, H., Banach, A., \& Larm, T. (2010). Occurreence and treatment of priority substances, metals and other substances in stormwater. Stockholm: SVU.

Bartlett, A. J., Rochfort, Q., Brown, L. R., \& Marsalek, J. (2012a). Causes of toxicity to Hyalella azteca in a stormwater management facility receiving highway runoff and snowmelt. Part II: salts, nutrients, and water quality. Science of the Total Environment, 414, 238-247.

Bartlett, A. J., Rochfort, Q., Brown, L. R., \& Marsalek, J. (2012b). Causes of toxicity to Hyalella azteca in a stormwater management facility receiving highway runoff and snowmelt. Part I: polycyclic aromatic hydrocarbons and metals. Science of the Total Environment, 414, 227-237.

Boom, A., \& Marsalek, J. (1988). Accumulation of polycyclic aromatic hydrocarbons (PAHs)in urban snowpack. The Science of the Total Environment, 74, 133-148.
Buffle, J., \& Leeuwen, H. P. v. (1992). The use of filtration and ultrafiltration for size fractionation of aquatic paticles colloids and macromolecules. In Environmental particles Volume (Vol. 1, pp. 171-230). Lewis Publishers.

Choi, H., Harrison, R., Komulainen, H., \& Saborit, J. M. D. (2010). Polycyclic aromatic hydrocarbons. In WHO guidelines for indoor air quality: selected pollutants (pp. 289346).

Colbeck, S. C. (1981). A simulation of the enrichment of atmospheric pollutants in snow cover runoff. Water Resources Research, 17(5), 1383-1388.

Couillard, D. (1982). Toxicite des eaux de ruissellement de la fonte de neige en milieu urbain (toxicity assessment of snowmelt water runoff in an urban area)- in French. Water Research, 16(7), 1197-1205.

Croghan, C. W., \& Egeghy, P. P. (2003). Methods of dealing with values below the limit of detection using SAS. In Southeastern SAS User Group, St. Petersburg, FL.

Droste, R. L., \& Johnston, J. C. (1993). Urban snow dump and pollutant reduction in snowmelt by sedimentation. Canadian Journal of Civil Engineering, 20(1), 9-21.

Elik, A. (2001). Monitoring of heavy metals in urban snow as indicator of atmosphere pollution. International Journal of Environmental Analytical Chemistry, 82(1), 37-45.

Engelhard, C., De Toffol, S., Lek, I., Rauch, W., \& Dallinger, R. (2007). Environmental impacts of urban snow management - the alpine case study of Innsbruck. Science of the Total Environment, 382, 286-294.

Exall, K., Marsalek, J., Rochfort, Q., \& Kydd, S. (2011). Chloride transport and related processes at a municipal snow storage and disposal site. Water Quality Research Journal of Canada, 46(2), 148-156.

Field, R., Struzeski, E. J., Masters, H. E., \& Tafuri, A. N. (1974). Water pollution and associated effects from street saltation. Journal of the Environmental Engineering Division, 100(2), 459-477.

Glenn, D. W., \& Sansalone, J. J. (2002). Accretion and partitioning of heavy metals associated with snow exposed to urban traffic and winter storm maintenance activities. II. Journal of Environmental Engineering, 128(2), 167-185.

Guéguen, C., \& Dominik, J. (2003). Partitioning of trace metals between particulate, colloidal and truly dissolved fractions in a polluted river: the Upper Vistula River (Poland). Applied Geochemistry, 18(3), 457-470.

Hautala, E.-L., Rekilä, R., Tarhanen, J., \& Ruuskanen, J. (1995). Deposition of motor vehicle emissions and winter maintenance along roadside assessed by snow analyses. Environmental Pollution, 87(1), 45-49.

Helsel, D. R. (1990). Less than obvious: statistical treatment of data below the detection limit. Environmental Science \& Technology, 24(12), 1766-1774.

Huerta-Diaz, M. A., Rivera-Duarte, I., Sañudo-Wilhelmy, S. A., \& Flegal, A. R. (2007). Comparative distributions of size fractionated metals in pore waters sampled by in situ dialysis and whole-core sediment squeezing: implications for diffusive flux calculations. Applied Geochemistry, 22, 2509-2525.

Judd, J. H. (1970). Lake stratification caused by runoff from street deicing. Water Research, 4(8), 521-532.

Kuoppamäki, K., Setälä, H., Rantalainen, A.-L., \& Kotze, D. J. (2014). Urban snow indicates pollution originating from road traffic. Environmental Pollution, 195, 56-63. 
Leermakers, M., Phrommavanh, V., Drozdzak, J., Gao, Y., Nos, J., $\&$ Descostes, M. (2016). DGT as a useful monitoring tool for radionuclides and trace metals in environments impacted by uranium mining: case study of the Sagnes wetland in France. Chemosphere, 155, 142-151.

Li, X., Jiang, F., Wang, S., Turdi, M., \& Zhang, Z. (2015). Spatial distribution and potential sources of trace metals in insoluble particles of snow from Urumqi, China. Environmental Monitoring and Assessment, 187(1), 4144.

Luan, H., \& Vadas, T. M. (2015). Size characterization of dissolved metals and organic matter in source waters to streams in developed landscapes. Environmental Pollution, 197, 7683.

Malmquist, P.-A. (1978). Atmospheric fallout and street cleaningeffects on urban water and snow. Programme of Water Technology, 10(5/6), 495-505.

Malmquist, P.-A. (1984). Environmental effects of snow disposal in Sweden. In Minimizing the environmental impact of the disposal of snow from urban areas (pp. 74-81).

Markiewicz, A., Björklund, K., Eriksson, E., Kalmykova, Y., Strömvall, A.-M., \& Siopi, A. (2017). Emissions of organic pollutants from traffic and roads: priority pollutants selection and substance flow analysis. Science of the Total Environment, 580, 1162-1174.

Marsalek, J. (2003). Road salts in urban stormwater: an emerging issue in stormwater management in cold climates. Water Science and Technology, 48(9), 61-70.

Marsalek, J., Oberts, G., Exall, K., \& Viklander, M. (2003). Review of operation of urban drainage systems in cold weather: water quality considerations. Water Science and Technology, 48(9), 11-20.

McKenzie, E. R., \& Young, T. M. (2013). A novel fractionation approach for water constituents - distribution of storm event metals. Environmental Science: Processes \& Impacts, 15(5), 1006-1016.

Meyer, T., Lei, Y. D., Ibrahim, M., \& Wania, F. (2009a). Organic contaminant release from melting snow. 1. Influence of chemical partitioning. Environmental Science \& Technology, 43, 657-662.

Meyer, T., Lei, Y. D., Ibrahim, M., \& Wania, F. (2009b). Organic contaminant release from melting snow. 2. Influence of snow pack and melt characteristics. Environmental Science \& Technology, 43(3), 663-668.

Meyer, T., Lei, Y. D., \& Wania, F. (2006). Measuring the release of organic contaminants from melting snow under controlled conditions. Environmental Science \& Technology, 40(10), 3320-3326.

Meyer, T., Lei, Y. D., \& Wania, F. (2011). Transport of polycyclic aromatic hydrocarbons and pesticides during snowmelt within an urban watershed. Water Research, 45(3), 1147-1156.

Moghadas, S., Paus, K. H., Muthanna, T. M., Herrmann, I., Marsalek, J., \& Viklander, M. (2015). Accumulation of traffic-related trace metals in urban winter-long roadside snowbanks. Water, Air, \& Soil Pollution, 226(12), 404.

Morrison, M. A., \& Benoit, G. (2005). Temporal variability in physical speciation of metals during a winter rain-on-snow event. Journal of Environmental Quality, 34(5), 1610-1619.

Novotny, V., Muehring, D., Zitomer, D. H., Smith, D. W., \& Facey, R. (1998). Cyanide and metal polution by urban snowmelt: impact of deicing compounds. Water Science and Technology, 38(10), 223-230.
Oberts, G. L., Marsalek, J., \& Viklander, M. (2000). Review of water quality impacts of winter operation of urban drainage. Water Quality Research Journal of Canada, 35(4), 781-808.

Reader, J. P., \& Dempsey, C. H. (1989). Episodic changes in water quality and their effects on fish. In R. Morris, E. W. Taylor, D. J. A. Brown, \& J. A. Brown (Eds.), Acid toxicity and aquatic animals (pp. 67-83). Cambridge: Cambridge University Press.

Reader, J. P., Everall, N. C., Sayer, M. D. J., \& Morris, R. (1989). The effects of eight trace metals in acid soft water on survival, mineral uptake and skeletal calcium deposition in yolk-sac fry of brown trout, Salmo trutta L. Journal of Fish Biology, 35(2), 187-198.

Reinosdotter, K., \& Viklander, M. (2005). A comparison of snow quality in two Swedish municipalities - Luleå and Sundsvall. Water, Air, and Soil Pollution, 167(1-4), 3-16.

Reinosdotter, K., \& Viklander, M. (2007). Road salt influence on pollutant releases from melting urban snow. Water Quality Research Journal of Canada, 42(3), 153-161.

Reinosdotter, K., Viklander, M., \& Malmqvist, P. A. (2006). Polycyclic aromatic hydrocarbons and metals in snow along a highway. Water Science and Technology, 54(6-7), 195203.

Ruth, O. (2003). The effects of de-icing in Helsinki urban streams, Southern Finland. Water Science and Technology, 48(9), 3343.

Sakai, H., Sasaki, T., \& Saito, K. (1988). Heavy metal concentrations in urban snow as an indicator of air pollution. The Science of the Total Environment, 77(2-3), 163-174.

Sansalone, J. J., \& Glenn, D. W. (2002). Accretion of pollutants in snow exposed to urban traffic and winter storm maintenance activities. I. Journal of Environmental Engineering, 128(2), 151-166.

Schöndorf, T., \& Herrmann, R. (1987). Transport and chemodynamics of organic micropollutants and ions during snowmelt. Hydrology Research, 18(4-5).

Schrimpff, E., Thomas, W., \& Herrmann, R. (1979). Regional patterns of contaminants (PAH, pesticides and trace metals) in snow of Northeast Bavaria and their relationship to human influence and orographic effects. Water, Air, and Soil Pollution, 11(4), 481-497.

Stone, M., \& Marsalek, J. (2011). Adoption of best practices for the environmental management of road salt in Ontario. Water Quality Research Journal of Canada, 46(2), 174-182. https://doi.org/10.2166/wqrjc.2011.105.

Swedish Standards Institute (2005). SS-EN 872:2005 Water quality - determination of suspended solids - methods by filtration through glass fibre filters, SIS. Swedish standard institute, 2005.

Tuccillo, M. E. (2006). Size fractionation of metals in runoff from residential and highway storm sewers. Science of the Total Environment, 355(1-3), 288-300.

U.S. Environmental Protection Agency (EPA). (1983). Results of the Nationwide Urban Runoff Program. Vol. 1 - Final Report. Report WH-554, U.S. EPA, Water Planning Division, Washington, D.C.

Valtanen, M., Sillanpää, N., \& Setälä, H. (2014). The effects of urbanization on runoff pollutant concentrations, loadings and their seasonal patterns under cold climate. Water, Air, and Soil Pollution, 225(6). 
Vasić, M. V., Mihailović, A., Kozmidis-Luburić, U., Nemes, T., Ninkov, J., Zeremski-Škorić, T., \& Antić, B. (2012). Metal contamination of short-term snow cover near urban crossroads: correlation analysis of metal content and fine particles distribution. Chemosphere, 86(6), 585-592.

Venner, M., \& Zeimer, L. (2004). Environmental stewardship practices, procedures, and policies for highway construction and maintenance- chapter 8: winter operations and salt, sand and chemical management.

Viklander, M. (1996). Urban snow deposits-pathways of pollutants. The Science of the Total Environment, 189/190, 379384.

Viklander, M. (1997). Snow quality in urban areas- $\mathrm{PhD}$ thesis. In Lulea University of Technology.

Viklander, M. (1998). Snow quality in the city of Lulea, Sweden time variation of lead, zinc, copper and phosphorus. The Science of the Total Environment, 216(1-2), 103-112.

Viklander, M. (1999). Substances in urban snow. A comparison of the contamination of snow in different parts of the city of Luleå, Sweden. Water, Air, \& Soil Pollution, 114(3), 377394.

Wang, W., Wen, B., Zhang, S., \& Shan, X.-Q. (2003). Distribution of heavy metals in water and soil solutions based on colloidsize fractionation. International Journal of Environmental Analytical Chemistry, 83(5), 357-365.

Warren, L. A., \& Zimmerman, A. P. (1994). The influence of temperature and $\mathrm{NaCl}$ on cadmium, copper and zinc partitioning among suspended, particulate and dissolved phase in an urban river. Water Research, 28(9), 1921-1931.

Wei, Y., Liu, S., Wang, Z., Wang, Z., \& Wang, S. (2017). The distribution variation of polycyclic aromatic hydrocarbons between fresh snow and seasonal snowpack in campus in Changchun City, Northeast China. Water, Air, and Soil Pollution, 228(7), 11.

Westerlund, C., \& Viklander, M. (2005). Particles and associated metals in road runoff during snowmelt and rainfall. Science of the Total Environment, 362(1), 143-156.

Westerlund, C., \& Viklander, M. (2011). Pollutant release from a disturbed urban snowpack in northern Sweden. Water Quality Research Journal of Canada, 46(2), 98-109.

Westerlund, C., Viklander, M., Nordqvist, K., Galfi, H., \& Marsalek, J. (2011). Particle pathways during urban snowmelt and mass balance of selected pollutants, in $12 \mathrm{th}$ International Conference on Urban Drainage. Porto Alegre/Brazil.

Xue, B.-X., Wei, L., Li, C.-Y., \& Li, T.-Y. (2015). A study of the distribution and composition of pollutants in snow collected from streets and a treatment system for recycling snow in winter cities. s. Desalination and Water Treatment, 54(4-5), $1470-1478$.

Yoon, S.-H. (2016). Classification of membranes according to pore size. In A. J. Forsgren (Ed.), Membrane bioreactor processes: Principles and applications. Taylor and Fransis Group.

Publisher's Note Springer Nature remains neutral with regard to jurisdictional claims in published maps and institutional affiliations. 